\title{
ESTUDIOS
}

\section{José Martí y Manuel Gutiérrez Nájera: Iniciadores del Modernismo (1875-1877)}

W ${ }_{\text {diez }}^{\text {años son de capital importancia. Durante esta década, la in- }}$ vestigación, auxiliada por la estilística, ha revalorado aquel movimiento renovador, ha rectificado la fecha de su aparición y señalado con precisión quiénes fueron sus auténticos iniciadores. Por otra parte, se ha dilucidado su evolución y bifurcación en dos fases o modalidades estilisticas desde el principio. En este proceso Rubén Darío ocupa un lugar preeminente y hasta culminante por lo que a la poesia en verso respecta, pero no inició ninguna de las dos corrientes en que el modernismo se orientó. Otra conquista de la crítica en el curso de los últimos dos Iustros ha consistido en el reconocimiento de la importancia artística de la prosa. Fue en esta expresión, y no en el verso, donde se produjo la revolución estética unos diez o doce años antes de que se diera idéntica transformación en el verso.

Por más de medio siglo la crítica venía afirmando que el modernismo empezó en r888 con la publicación de $A z u l$.. La verdad histórica ha resultado ser otra. Los albores de este movimiento se remontan al lustro I875-1880 cuando José Martí y Manuel Gutiérrez Nájera ensayaron en su prosa formas de innovación estilísticas pertenecientes a una estética que luego se denominaría "modernista". De esta estética no eran Martí, Nájera, Casal y Silva los precursores-noción muy divulgada y aceptada por la crítica tradicional-sino modernista ciento 
por ciento. Las pesquisas contemporáneas, al rectificar el falaz concepto de "precursores" que en algunos casos escribieron obra en verso y prosa posterior a la aparición de $A z u l . .$. , han revelado que este movimiento sí tuvo sus precursores, pero éstos no fueron los arriba mencionados poetas y prosistas, sino artistas anteriores como Sarmiento, Cané, Altamirano, Hostos, Varona, Montalvo, Pombo, Pérez Bonalde, Sierra, etc., y, en España, Bécquer y Rosalía de Castro, para mencionar algunos de los más destacados.

El sistemático estudio estilístico de la literatura americana de la década del 70 y principios de la del 80 que la crítica moderna inició, ha traído consigo la revaloración de la prosa colorida y musical anterior a la de Dario, y, a la vez, ha demostrado que a la prosa le cupo el honor de inaugurar el modernismo.

La prosa modernista, tan rica en imágenes, variada en ritmos, plástica y sensual, siguió dos tendencias expresivas - al igual que la expresión poética posterior-ya de 1876 a I882, y, no se reducía, como se creia, al venero preciosista, escapista, frivolo y afrancesado de $A z u l . .$. La primera de estas dos facetas estilísticas la representa José Martí, quien reemplazó la anquilosada expresión literaria de su momento con una prosa de oriundez hispánica, enraizada en el arte de los clásicos del Siglo de Oro español - Santa Teresa, Cervantes, Quevedo, Gracián, Saavedra Fajardo-y, enriquecida con las más recientes y exquisitas expresiones de la literatura europea coeval, principalmente la francesa. Todo ello lo plasmó el Maestro en un conjunto armónico, cromático y profundamente suyo. Al mismo tiempo, Martí tenía, no sólo conciencia sino volición de la transformación que estaba operando en las letras hispánicas, como lo prueba el nutrido cuerpo de ideas teóricas que a partir de I875, acompañan sus innovaciones formales.

Durante esta misma época - I876-1882- otra figura, Manuel Gutiértez Nájera, cultivaba una prosa de distintas características, de pareja importancia en la renovación modernista, la cual representa la segunda de las dos tendencias expresivas arriba mencionadas. El Duque Job prefería un estilo afrancesado, de giros y vocablos franceses, de ambientes parisienses, y de temas frívolos aprendidos de Mendès, Coppée, Musset, Paul de Saint Victor y Gautier. En él, a diferencia de Martí, las influencias foráneas no siempre están asimiladas y convertidas en procedimiento pro. pio y, por lo tanto, se manifiestan de manera directa. De las dos maneras expresivas, la de Martí y la de Nájera, prevaleció en definitiva la prosa martiana de entronque hispánico, pues a la postre, tanto "El 
Duque" como el mismo Rubén terminaron abandonando el estilo afrancesado como vehículo exclusivo de expresión.

Esstos, en síntesis, son algunos de los más relevantes conceptos recientes sobre el modernismo, expuestos y defendidos por nosotros con anterioridad, ${ }^{1}$ los cuales nos obligan a resumir y repetir el artículo polémico "Gutiérrez Nájera y Martí como iniciadores del Modernismo", por Boyd G. Carter, publicado en el número 54 de esta revista. Tomando pie en el ensayo del profesor Carter, se escribe este estudio con la intención de rectificar o dilucidar algunos deslices de índole estética e ideológica notados en dicho ensayo, rebatir la infundada concepción sostenida por el doctor Carter de que nos interesa empequeñecer la figura del poeta y prosista mexicano ${ }^{2}$ y, al mismo tiempo, contribuir al mayor conocimiento del período primigenio de Martí y Nájera: $1875-1877^{3}$

Antes de pasar al examen de estos años, insuficientemente explorados por los estudiosos de la obra de Martí y Nájera, sería oportuno recordar, además del indispensable libro Breve bistoria del modernismo por Max Henríquez Ureña, tres valiosos ensayos de Federico de Onís aparecidos en I952, I953 y 1956 respectivamente. El primero "José Martí: Vida y obra, Valoración", se publicó en el númeto conmemorativo del centenario de José Martí que le consagró la Revista Hispánica Moderna (XVIII, I45-I5O); el segundo apareció en la Memoria del Congreso de Escritores Martianos (La Habana, 43I-446) intitulado "Martí y el modernismo"; y el tercero "La poesía hispanoamericana" en Cuddernos (2I, II-I9). Los dos primeros, que son los de mayor significación en este caso, fueron reproducidos en la Antología crítica de José

1 En "Los supuestos 'precursores' del modernismo hispanoamericano", Nueva Revista de Filología Hispánica, XII (1958), 61-64.

$2 \mathrm{El}$ anigo Carter op. cit. se obstina en probar mi intento de rebajar a Nájera y quitarle la gloria de co-iniciador del modernismo (p. 295). En defensa de tal afirmación enumera una serie de páginas de mi libro Símbolo y color en la abra de José Martí (Madrid: Gredos, 1960), "todas encaminadas al propósito de demostrar la prioridad de Martí sobre Gutiérrez Nájera en el uso de colores" (p. 297). En estas citas, amén de varias otras, admito la contribución de Nájera a la iniciación del modernismo. Si afirmo que Martí antecede a Nájera en la cuestión cromática es porque tal afirmación responde a los hechos como se verá más adelante. Baste decir por el momento que el profesor Carter sólo reproduce un ejemplo del uso del azul por parte de Nájera en 1875, aparte de otro de paternidad dudosa y de carácter miméíico - no modernista- de 1874 (p. 299).

3 Sobre este período de la obra martiana debe consultarse el valiosísimo ar. tículo de Manuel Pedro González "Conciencia y voluntad de estilo en Martí, 1875-1880" en Libro jubilar de Emeterio S. Santovenia en su cincuentenario de escritor, La Habana, 1957, pp. 191-227, reproducido en Indagaciones martianas (La Habana: Universidad Central de las Villas, 1961), 83-139. Desgraciadamente el profesor Carter, según su propia confesión (p. 297, n. 7), no ha leído este estudio alusivo al tema. 
Martí (México: Cultura, I960) recopilada por Manuel Pedro González, libro esencial también -y más aún el titulado José Martí. Esquema ideológico, publicado por la Editorial Cultura en I96I- para el cabal conocimiento del gran cubano.

En el susodicho estudio de r956, Onís sintetizó los rectificados conceptos sobre la génesis y las características del modernismo y, enmendando nociones anticuadas, sentenció que

...el Modernismo - como el Renacimiento o el Romanticismo- es una época y no una escuela, y la unidad de esa época consistió en producir grandes poetas individuales, que cada uno se define por la unidad de su personalidad, y todos juntos por el hecho de haber iniciado una literatura independiente, de valor universal, que es principio y origen del gran desarrollo de la literatura hispanoamericana posterior.4

A continuación, Onís destaca la labor de José Martí como la del "primero y más grande de los creadores de esta época", 5 cuya obra, tanto en prosa como en verso, inicia modalidades estilísticas - las modernistas- de influencia rectora hasta hoy. ${ }^{6}$ En este mismo enjundioso estudio que estamos giosando, se rebate también la tan reiterada e infundada concepción del desarrollo del modernismo, según la cual se repite que Martí, Nájera, Casal y Silva son precursores y no modernistas cabales; Onís les confiere a todos la categoría de modernistas: "Contemporánea de él [Martí] es la primera generación de poetas modernistas, que suelen llamarse precursores, pero que en rigor son los creadores de la nueva literatura en el verso y la prosa. ." A este respecto es significativa la opinión expresada

4 Onís, "Lo poesía hispanoamericana", p. 17.

5 Loc. cit.

6 Loc, cit.

7 Loc. cit. Llamarlos creadores o iniciadores no es un mero juego semántico como quiere sugerir Bernardo Gicovate en su libro reciente Conceptos fundamen. tales de literatura comparada (San Juan: Asomante, 1962), pp. 39.40. Se trata de una rectificación de la cronología del movimiento modernista, y de una revaloración de la gran aportación de Martí, Nájera, Casal y. Silva. A pesar de que con anterioridad al estudio de Onis, críticos como Max Henríquez Ureña en su Breve bistoria del modermismo. $1^{a}$ ed. (México: Fondo de Cultura Económica. 1954), habian rechazado la idea de llamar a estos artistas "precursores del mo. dernismo", se sigue cultivando esta equivocada concepción. Como ejemplos véanse Luis Lamothe, Los mayores poetas latinamericanos de 1850 a 1950 (México: Libro Mex, 1959) y Raúl Silva Castro, Antología crítica del modernismo bispano. ainericano (Nueva York: Las Américas, 1963). Silva Castro utiliza el nombre "precursores" a sabiendas de que "es en ciertos puntos equívaco" p. 39). Reconoce que las obras de los "precursores" "corren paralelas a las de Rubén 
en 1895 por el modernista panameño Darío Herrera - y olvidada por la crítica posterior- de que Marti y Nájera iniciaron la época modernista. Desgraciadamente, aún hoy algunos críticos prefieren fijarse en las ególatras afirmaciones de Dario, quien se declaró, en más de una ocasión, iniciador del modernismo, ${ }^{8}$ y se obstinan en creer que el modernismo principió en $1888,{ }^{9}$ con menoscabo de la obra renovadora de los así llamados "precursores" y de los hechos históricos. Dario Herrera, en cambio, vio con claridad el problema histórico cuando criticó la aseveración de Clemente Palma de que Darío y Casal, ellos solos, habían iniciado el modernismo; su opinión disidente está confirmada por las investigaciones modernas en torno a la cronología del modernismo.

Para mí-sentenció- Darío y Casal han sido los propagadores del modernismo, pero no los iniciadores. Este título corresponde más propiamente a José Martí —olvidado por Palma en las citas que hace de los modernistas americanos-y a Manuel Gutiérrez Nájera. Ambos vinieron a la vida literaria mucho antes que Darío y Casal, y eran modernistas cuando todavía no había escrito Dario su $A z u l$ ni Casal su Nieve. ${ }^{10}$

La historia de esta novadora época literaria --considerando las expresiones artísticas de prosa y verso que en ella se dieron- revela que dos insignes escritores, uno cubano y mexicano el otro, José Martí y Manuel Gutiérrez Nájera, encontrándose en México durante 1875-1876, iniciaron alli la literatura modernista, ${ }^{11}$ sobre todo en lo que a la prosa atañe. ${ }^{12}$

Darío" (loc. cit.) pero el concepto de Darío como el primer modernista parece regir sus ideas e impide la aceptación de una nueva visión del modernismo, movimiento que según el crítico chileno se debe a un solo hombre (p. 18). Contra estas ideas anquilosadas estaban dirigidas algunas afirmaciones de mi libro Simbolo y color en la obra de José Martí (Madrid: Gredos, 1960), y no, como erróneamente afirma Carter (op, cit., p. 295), para demostrar la prioridad de Martí sobre Nájera.

8 V. el prólogo a Cantos de vida y esperanza (1915): "El movimiento literario que me tocó iniciar en América" [Obras completas (Madrid: Mundo Latino 1918), VII, 9]; y, en 1896, respecto a $A z u l . .$. , afirmó: "Y he aquí como, pensando en francés y escribiendo en castellano... publiqué el pequeño libro que iniciaría el actual movimiento literario americano..." ["Los colores del estandarte" en Escritos inéditos de Rubén Darío (Nueva York: Instituto de las Españas, 1938), p. 121].

9 V. por ejemplo Raúl Silva Castro, op, cit., p. 29, guien cita la opinión de Arturo Torres Ríoseco al respecto, y sostiene la idoneidad de esta concepción cronológica.

10 La opinión de Darío Herrera fue publicada en julio de 1895, y reproducida en la Revista Dominicana de Cultura, 2 (1955), 255-256.

11 Este concepto lo expresamos en 1958 en el artículo citado en la nota 1.

12 Sobre la prioridad de la prosa en el desarrollo de la expresión modernista, v. nuestro estudio 'Los supuestos 'precursores' del modernismo hispanoamericano". p. 62. 
Ignoramos todavia todas las peripecias de las relaciones entre estas dos figuras cumbres, pero la documentación a nuestro alcance indica que en I876 se establece el nexo entre Martí y Nájera cuando éste, en tono elogioso, alude a "...los notables escritores Azcárate, Sosa y Martí".13 Al año siguiente - $\mathrm{I} 877^{-}$, comentando los Ensueños de Pedro Castera, en carta abierta a Heberto Rodríguez," Nájera dice: "Pedro Castera sigue la escuela de Uhland y Rückert, como usted sigue paso a paso la gongórica escuela de Marti"' (Obras I, I67-I68). ${ }^{15}$ El barroquismo ideológico martiano, al cual alude en la cita del 77 , siguió desconcertando al poeta mexicano en años posteriores, según la confesión incluida en su artículo sobre la "Edad de Oro" de Martí ( I889). Sirviéndose de imágenes del Maestro ${ }^{16}$ y de sintagmas anafóricos de estructura martiana, asimismo, dice: "Martí, cuyas ideas no podemos seguir a veces porque sus ideas tienen las alas recias, fuerte el pulmón y suben mucho; Martí, en cuyo estilo mágico nos solemos perder de cuando en cuando..." (Obras $\left.1,37^{2}\right)$. $Y$, en I89o, cuando el autor de los Cuentos frágiles le dirigió al Apóstol una carta que dejó inconclusa en su mesa de redacción, ${ }^{17}$ se declaró deudor de Martí, hecho que el estudio sistemático de la prosa najeriana-en particular la posterior al 82 - pondría en claro, revelando ser verdaderas las

13 Obras: Crítica literaria, I (México: Universidad Nacional Autónoma, 1959), p. 144. De aquí en adelante usaremos dentro del texto la forma abreviada Obras $I$, seguida de la página para referirnos a este volumen.

14 Martí se dirigió al mismo poeta y crítico un año antes-1876- defendiendo, como Nájera, el amor como fuente de la poesía [Obras completas (La Habana: 'Trópico, 1936-1953), L. 12]. En adelante, al referimos a esta edición usaremos números arábicos para indicar el volumen y la página; se indicará primero el volumen, y luego la página.

15 Martí también escribió sobre la obra de Pedro Castera-en 1.875-pero entre el estudio de Martí "Versos de Pedro Castera" (50:21-29) y el de Nájera no hay relación significativa.

16 Como ejemplo de imagen martiana: "Qué no soplen sobre las alas de esa mariposa, porque el oro de esas alas se irá al rayo del sol, como a su patria!" (Obras I, 371). Recuérdese que Martí escribió un volumen de versos intitulado Polvo de alas de mariposa (ca. 1882), y que en carta a Manuel A. Mercado (1882) se sirvió de la misma imagen: ". . no daré al aire esa mariposa de mayor estio [hasta] que no me diga U. si le parece que llevan bien cargadas de polvo de oro, y de fortaleza las alas..." (68:92). En cuanto a las construcciones, v. la sentencia citada en parte en el texto y que a continuación completamos, de filiación oratoria y de oriundez ciceroniana que stanto abunda en el estilo de Martí: "Mart'́, cuyas ideas no podemos seguir a veces, porque sus ideas tienen las alas recias... Marti, en cuyo estilo mágico nos solemos perder de cuando en cuando... Martí, para escribir La Edad de Oro ha dejado de ser río y se ha hecho lago, terso, transparente, límpido" (Obras l, 372) (El subrayado es mío).

17 Recogida y reproducida por Margatita Gutiérrez Nájera en su hermoso y valioso libro Reflejo (México: Instituto Nacional de Bellas Artes, 1960), p. 153. 
palabras de Nájera: "Me considero deudor a U. de muchas gotas de luz, de muchos diamantes, de muchos ramos de flores, y - lo que es más- de muchas ideas que ennoblecen mi espíritu y que me reconcilian con esquivos ideales". 18

Martí, por su parte, se acordó de Nájera con gran cariño, y lo mencionó repetidas veces en sus cartas, sobre todo a Manuel A. Mercado. Tres meses después de la muerte del "Duque", la víspera de su propia inmolación en Dos Ríos, escribió el Apóstol a Mercado, su entrañable amigo mexicano:

$Y$ ahora, puesto delante lo de interés público, le hablaré de mí, ya que sólo la emoción de este deber pudo alzar de la muerte apetecida al hombre que, ahora que Nájera no vive donde se le vea, mejor lo conoce y acaricia como un tesoro en su corazón la amistad con que Ud. lo enorgullece. (8:275)

Al principio del mismo año - en enero- dio Martí expresión a su estimación por el poeta mexicano en Patria:

Por su imparcial y vasto corazón es aún más notable Manuel Gutiérrez Nájera que por el marfil y el oro de su verso:19 va por el mundo como fuera de él, no porque a la hora de la fatiga no le conozca las prácticas y bastidores, y pueda en él lucir y guiar, sino porque tiene en sí, y en su recuerdo vívido de las obras de beldad excelsas, como suprema y preferible compañía. ( $44:$ I97)

Pero, el afectuoso trato entre los dos modernistas comenzó antes, ${ }^{20}$ en r888. En su íntima correspondencia con el "hermano" mexicano, Manuel

18 En 1890 Nájera le mencionó otras veces. En su artículo sobre La bija del rey de José Peón y Contreras dijo: "Una cabeza verídica de genio, con mirada embustera de mal genio: Pepe Martí" y, "...hace falta en el teatro la cabeza de genio de José Marti" (Obras $7,408-411$ ). V. también las pp. 214-221 del libro de José de J. Núñez y Domínguez Martí en México (México: Secretaría de Relaciones Exteriores, 1934) y el de Margarita Gutiérrez Nájera (op. cit.) sobre las relaciones entre Martí y Nájera.

19 Ya en 1892 había utilizado estas dos figuras al referirse a Nájera en la página titular de un ejemplar de Versos sencillos que le dedicó: "A Manuel Gutiérrez Nájera-marfil en el verso, en la prosa seda, en el alma oro: su José Marti" [Exposición documental de Manuel Gutiérrez Nájera (1859-1959), ed. Ernesto Mejía Sánchez, (México: Dirección General de Publicaciones, 1959), p. 51].

20 Hay alusiones a Nájera en fecha tan temprana como 1876 (65:29), pero antes de 1888 es difícil encontrar ejemplos reveladores de un intimo nexo amis- 
A. Mercado, abundan las alusiones a Nájera a partir de este año. De julio del 88 es este hermoso testimonio de cariño que es, a la vez, un reconocimiento de la labor renovadora de Nájera:

A quien no se puede tachar de incorrecto, y a quien le prologaré el libro y le cuidaré la impresión con muchísimo gusto, es a Gutiérrez Nájera, a quien mando por Ud. todo mi agradecimiento por el afecto con que piensa en mí, y yo le pago bien, porque lo merece cuanto sé de él y veo escrito. Es de los pocos que está trayendo sangre nueva al castellano y de los que mejor esconden las quebraduras y hendijas inevitables de la rima. Más hace; y es dar gracia y elegancia al idioma español al que no faltaba antes gracia, pero placeril y grosera. $Y$ eso lo hace Gutiérrez sin afectación, y no porque tome de modelo a éste o aquél, aunque se ve que conoce intimamente, y ama con pasión, lo perfecto de todas las literaturas; sino por invencible tendencia suya a hermanar la sinceridad y la belleza. (68:19I-I92)

Si en las líneas anteriores es el artista el encomiado, en los pensamientos siguientes del 89 se transparenta la alabanza al hombre, del valor humano:

...estimo mucho a Nájera, no tanto por su talento, que es extraordinario, como por la nobleza de su corazón. Todo lo que se [sic] hace es bello; y mucho, perfecto. Yo, que brego con el verso y la prosa, sé lo que vale el que brega y triunfa. Pensaba en él cuando escribía en días pasados, a propósito de otro, que tenía en su pluma todos los colores, menos el del veneno.21 (69:17)

Estos dos artistas que así se admiraban, cultivaban un arte innovador de naturaleza distinta, pero ambos anhelaban ensanchar las dimensiones expresivas del lenguaje literario castellano, traer, como decía Martí, "sangre nueva"; Martí buscaba plasmar sus "visiones" en una expresión que denotaba la presencia de las innovaciones estilísticas contemporáneas en

toso como éste: ". . porque alli me lo van a querer mucho, sus Sosas y Mercados, y sus Yzcalbacetas y mis Gutiérrez Nájera..." (67:175), entresacado de una carta dirigida a Vicente G. Quesada al prepararse éste para un viaje a México.

21 De este mismo año hay varias otras alusiones a Gutiérrez Nájera en cartas a Mercado, sobre todo con motivo de la publicación del artículo sobre La Edad de Oro. V. $69: 23 ; 69: 26 ; 69: 38-39 ; 69: 44-45$ y $69: 68$, donde se lee una simbólica frase imaginística precedida de una de sentido discursivo: "A Gutiérrez Nájera tengo que escribirle. Dejo entre tanto, un jacinto a su puerta". 
un molde hispánico de raíz clásica. Nájera, en cambio, cuyo estilo en prosa es de igual importancia que el de Martí desde el punto de vista de la renovación modernista, prefirió un arte en que lo francés - con frecuencia, lo sentimental y lo frivolo parisiense, expresado con "gracia y elegancia"- ocupó un lugar preeminente sin ser asimilado y convertido siempre (sobre todo en su obra primigenia) en procedimiento y técnica personales. ${ }^{22}$ Giros y vocablos procedentes del francés - y con excesiva frecuencia en el idioma original-abundan en la obra najeriana, a la cual no tendría acomodación la sentencia teórica martiana: "El uso de una palabra extranjera entre las palabras castellanas, me hace el mismo efecto que me haría un sombreto de copa sobre el Apolo de Belvedere" (64:177). Ambos se dieron cuenta cabal del decisivo momento literario en que vivía la América hispana, y de la imperante necesidad por introducir una literatura remozada. Testimonios de esta preocupación por el futuro de las letras americanas son sus pronunciamientos teóricos pertenecientes a la época que nos ocupa en este estudio: 1875 -1877.

\section{TEORÍA}

En 1876 Manuel Gutiérrez Nájera publicó un artículo en siete entregas intitulado "El arte y el materialismo" en el cual el joven poeta se reveló como el enemigo irreconciliable de "las desconsoladoras teorías del realismo, y del asqueroso y repugnante positivismo" (Obras $I, 50), 23 \mathrm{y}, \mathrm{a}$ la vez, defensor apasionado de la poesía sentimental. Boyd G. Carter, a cuya labor investigadora debemos la recopilación de este ensayo teórico del "Duque Job" lo considera "el primer manifiesto del modernismo"24 porque en él aboga Nájera por la libertad del proceso creador, la belleza como fin y objeto del arte, la utilidad de lo bello, y, el idealismo del arte. La valotación de Carter nos parece hiperbólica ${ }^{25}$ en vista de que los conceptos expresados en "El arte y el materialismo" pertenecen al venero espiritualista e idealista de las ideas estéticas que circulaban en América y en Europa por aquellas calendas formando parte del cuerpo de pensa-

22 Sobre este tema v. mi artículo "Los supuestos 'precursores' del modernismo hispanoamericano", pp. 62-63.

23 En Manuel Gutiérrez Nájera; Estudio y escritos inéditos (México: Studium, 1956); reproducido en Obras 1, 49-64.

24 En el libro de Carter, Manuel Gutiérrez Nájera; Estudio y escritos inéditos, p. 76. Carter reitera esta posición en su artículo polémico, p. 309.

$25 \mathrm{~V}$. nuestra opiniớn al respecto en "Nuevos textos inéditos de Gutiérrez Nájera", Revista Hispánica Moderna, XXIII (1957), 163-164. 
mientos teóricos de la época. De hecho, Porfirio Martínez Peñaloza ha señalado estas coincidencias ideológicas, vinculando los pronunciamientos najerianos expuestos en "El arte y el materialismo" con los de Hegel;26 nosotros, en I957, apuntamos su parentesco con las expresiones teóricas de Víctor Hugo en su prefacio a Cromwell; ${ }^{27}$ y el mismo Carter menciona otras posibles fuentes, a saber, Gautier, Lamartine y Francisco Zarco. ${ }^{28} \mathrm{El}$ parecido conceptual con el prefacio a Mademoiselle de Maupin (I835) de Gautier es en verdad asombroso, sobre todo en lo tocante a las ideas sobre lo bello y lo útil. ${ }^{29}$ Pero, no por revelar la ascendencia de otros creadores, asignamos a este escrito juvenil de Nájera un valor secundario en la historiografía de la estética modernista, negando al mismo tiempo que se le considere manifiesto - el primero- del modernismo, 30 sino porque hay en el consabido ensayo muy poco de las ideas renovadoras que asociamos con el modernismo. El único retoño novador -en cuanto a las ideas $^{31}$ _ es la insistencia sobre la libertad del artista, si bien tal afirmación es una declaración tardía de oriundez romántica:

Lo que nosotros queremos, lo que siempre hemos defendido, es que no se sujete al poeta a cantar solamente ciertos y determinados asuntos, porque esa sujeción, tiránica y absurda, ahoga su genio y sofocando tal vez sus más sublimes inspiraciones, le arrebata ese principio eterno que es la vida del arte, ese principio santo que es la atmósfera del poeta... (Obras $I, 52)$

Estas frases formuladas para combatir la envejecida tradición académica contra la cual se rebelaron los modernistas, contienen ideas que también aparecen en la teoría martiana correspondiente al mismo año, hecho que

26 V. Los números de México en la Cultura, suplemento literario de Novedades, correspondientes al 12 y al 27 de mayo de 1957.

27 En "Nuevos textos inéditos de Gutiérrez Nájera", p. 164.

28 "Gutiérrez Nájera y Martí como iniciadores del modernismo", p. 306.

29 Sobre lo bello dice Gautier: "Rien de ce qui este beau n'est indispensable a la vie", y de lo útil: "Il n'y a de vraiment beau que ce qui ne peut servir à rien: tout ce qui est utile est laid, car c'est l'expression de quelque besoin, et ceux de l'homme sont ignobles et dégoutants..." (París: Garnier, 1955, p. 23). Nájera resume sus pensamientos sobre la belleza y el idealismo en "El arte y el materia. lismo (Obras $I, 57$ ): "Pero si, como ya lo hemos dicho, la belleza reside en el orden espiritual y no en el de la materia, claro es que debemos encontrarla en el idealismo, que mira al cielo, y no en el materialismo, que fija sus ojos en la tierra".

30 Compárense estas ideas de Nájera con las expresadas por Martí en 1881 en un artículo publicado en la Revista Venezolana (20:26-33), fundada por Marti, y se verá la nimiedad novedosa de las ideas estéticas de "El arte y el materialismo". 31 Comentaremos el estilo más adelante. 
el profesor Carter pasó por alto al insistir sobre la trascendencia del escrito "El arte y el materialismo". Sobre la libertad artística dice Martí:

... porque antes que la retórica oprimiese el talento, el talento fue el creador de la retórica.

La regla no es más que el resultado de la observación entre talentos eminentes; luego, con talento nuevo no han de venir nuevas reglas? Las leyes son indudablemente respetables; pero, aunque parezca precepto revolucionario, no deben serlo tanto para quien sabe hacerlas. (50:150)

$$
\text { * * * }
$$

¡Reducir a una fórmula matemática la divina potestad cuya grandeza consiste en el desprecio absoluto de las fórmulas! No hay cátedras para el genio: él no sigue reglas, él las crea. (50:189-190)

Los conceptos libertadores de "El arte y el materialismo" se complementan y se afinan en " Romances', de Francisco de A. Lerdo" (x876) donde "El Duque" recomienda una relación estrecha entre forma y contenido:

Las formas poéticas no son, según nuestro entender, sino los instrumentos de que el poeta se sirve para producir en el ánimo de sus lectores el efecto de antemano preconcebido-- así pues, tienen que guardar una estrechísima conexión con la idea de que el autor se ha propuesto desarrollar en su obra. Tan ridícula fuera una composición a César escrita en seguidillas, como una humorística letrilla en la tobusta y levantada entonación de la oda. El asunto de una composición debe indicar desde luego cuál debe ser el metro que en ellas se use (Obras $\left.I, r_{49}\right){ }^{32}$

Además de "El arte y el materialismo", entre 1875 y 1877 , de la obra publicada - y fechada- de Nájera, sólo conocemos cuatro piezas en que la teoria literaria es de central relevancia: " Páginas sueltas' de Agapito Silva" ( 1876 ) donde se defiende otra vez la poesía sentimental y la libertad del artista; "Romances' de Francisco de A. Lerdo" (1876),

32 Años más tarde - -en 1890-en lenguaje metafórico Martí expresó idéntica idea: "Cada emoción tiene sus pies, y cada hora del día, y un estado de amor quiere dáctilos y anapestos la ceremonia de las bodas, y los celos quieren iambos. Un juncal se pintará con versos leves y como espigados, y el tronco de un roble con palabras rugosas, retorcidas y profundas" (12:186). 
artículo del que acabamos de citar un trozo sobre la equiparación de forma y fondo; "Un certamen literario" ( 1876 ), donde Nájera vuelve a considerar el problema de las reglas vis a vis la libertad creadora; $y$, por fin, "'Los ensueños' de Pedro Castera" (1877), ensayo en que se justifica el arte idealista, la poesía sentimental y el "lied" alemán.

En vista de que no hemos descubierto conceptos teóricos de índole revolucionaria en "El arte y el materialismo" ni en los demás escritos arriba enumerados, ${ }^{33}$ nos preguntamos en qué estriba la desmesurada importancia que el profesor Carter atribuye a un joven precoz de diecisiete años como iniciador de las ideas estéticas modernistas. En "El arte y el materialismo" no se descubre nada nuevo ni original. Nájera simplemente glosa conceptos mostrencos ya, por lo repetidos, y de limitada virtualidad renovadora.

De Martí no tenemos un escrito que exponga en forma orgánica sus multifacéticos conceptos sobre el arte literario, sino un cuerpo nutrido de ideas expresadas en forma fragmentaria en diversos artículos y apuntes de la época que estudiamos; estos escritos, sin embargo, amén de muchos posteriores a la era en cuestión revelan una honda y constante preocupación por los temas estéticos y la situación de las lettas americanas. ${ }^{34}$

Como Nájera, Martí adoptó una actitud crítica frente al ascendiente nocivo del positivismo, convertido en filosofía cuasi oficial, notando, en especial, el efecto deletéreo sobre las nacientes letras nacionales de México. En abril del 75, un año antes de que se publicara "El arte y el materialismo", Martí, recién ingresado socio del Liceo Hidalgo, tomó parto activa en las discusiones sostenidas en esta asociación literaria en torno a la influencia del espiritismo ${ }^{35}$ en el desarrollo de la ciencia y la literatura. El expatriado cubano "tomó la defensa del espíritu contra los más connotados materialistas de la época", 36 y planteó su posición filosófica con-

33 No podemos aceptar como criterio normativo la opinión de Carter: ". hasta que no se hayan publicado las obras completas de Gutiérrez Nájera, es evidente que no será posible hacer el balance de sus realizaciones como escritor y apreciar con plenitud los alcances de su genio" (Gutiérrez Nájera y Martí como iniciadores del modernismo", p. 310). Tenemos que juzgar según lo que conocemos de la obra publicada del Duque; lo mismo en el caso de Martí.

34 V. Alfredo A. Roggiano, "Poética y estilo de José Martí", Humanitas (Tucumán, Argentina), I (1953), 351-378, y los apartados intitulados "Teoría de la prosa y el estilo", (pp. 115-135); "Doctrina poética", (pp. 137-169); "Ideas sobre la literatura", (pp. 171-182) de José Martí, Esquema ideológico, ed. de Manuel Pedro González e Ivan A. Schulman (México: Cvltvra, 1961).

35 Este es el vocablo empleado por Núñez y Domínguez en su libro Martí en México que contiene una discusión muy detallada del debate. Martí vacila entre el uso de "espiritismo" y "espiritualismo"; varios periódicos de la época insistieron sobre el uso de "espiritismo". V. Núñez y Domínguez, op. cit., pp. 163-169.

36 Camilo Carrancá y Trujillo en José Martí, La clara voz de México (México: Imprenta Universitaria, 1953), p. 236. 
ciliadora en los siguientes términos: "Yo vengo a esta discusión con el espíritu de conciliación que norma todos los actos de mi vida. Yo estoy entre el materialismo que es la exageración de la materia y el espiritismo que es la exageración del espíritu' ${ }^{37}$ Lo mismo que Nájera en el consabido escrito teórico del $7^{6}$ sobre arte y materialismo, Martí, ante los miembros del Liceo Hidalgo, defendió el espíritu utilizando argumentos subjetivos; con sus "razones de sentimiento... el poeta cedió la palabra al filósofo, prestándole además, todas sus galas oratorias": ${ }^{38}$

¿Qué es el espíritu? ... es lo que en él piensa, lo que nos induce a actos independientes de nuestras necesidades corpóreas, es lo que nos fortalece, nos anima, nos agranda en la vida.

Con mi inconformidad en la vida, con mi necesidad de algo mejor, con la imposibilidad de lograrlo aqui, lo demuestro: lo abstracto se demuestra con lo abstracto, yo tengo un espíritu inmortal porque lo siento, porque lo creo, porque lo quiero. ${ }^{39}$

De Nájera son estas palabras, casi idénticas a las de Martí:

¿Qué es lo bello?

Si no lo sentís en vuestro espíritu, no pretendáis que nosotros os demos su definición; lo bello no se define, se siente. (Obras $I, 55$ ).

No se han publicado todos los discursos de las sesiones del Liceo desde la época en que, según Núñez y Domínguez, ${ }^{40}$ La Ilustración Espirita recogió en detalle las palabras acaloradas pronunciadas sobre el tema por Pimentel, Baz, Cordero, Villaseñor, Sierra Santiago y Martí. Sin embargo, existen suficientes pruebas para afirmar que en I875 Martí defendió la existencia del espíritu, concepto que forma la piedra angular de la estética expuesta en "El arte y el materialismo": "... lo bello no puede encontrarse en la materia, sino con relación al espíritu" (Obras I, 54).

37 Núñez y Domínguez, op. cit., p. 164.

38 Francisco F. Córdoba en su reseña de las sesiones, publicada en El Fede. ralista y reproducida por Núñez y Domínguez, op. cit., p. 167.

39 Citado por Núñez y Domínguez, op. cit., pp. 164-165 y 166.

40 Op. cit., p. 169. Sobre Martí y estas discusiones sobre el materialismo, v. también el libro de Alicia Perales Ojeda, Las asociaciones literarias mexicanas (México: Imprenta Universitaria, 1957), p. 110. 
Para trazar la génesis de las ideas teóricas martianas $y$, sobre todo, las coincidencias con las de Nájera, sigamos la intervención de Martí en las veladas organizadas por el Liceo Hidalgo, donde en 1876 , con motivo de honrar la memoria de la actriz, Señora Pilar Belaval de Muñoz se organizó una sesión extraordinaria en que Martí tomó parte, junto con Anselmo de la Portilla, Agustín F. Cuenca e Ignacio M. Altamirano. Una porción del discurso pronunciado por Martí versó sobre el tema del arte, definido por el apasionado orador en términos del espíritu y del amor, lo mismo que Nájera.

Dícese arte, y siéntese la voluntad encadenada a extraña y poderosa fuerza, y levantada la inspiración, y como cumplida una alegría, y regocijada y agradecida una ventura. Arte es huir de lo mezquino, y afirmarse en lo grande, y olvidarse, y enaltecerse, y vivir, porque olvidarlo es la única manera de perdonar al Creador ese don pesado, incomprensible y loco de la vida. (50:1 44 )

...y asciendan en aromas hacia la que adelanta por las sendas de la muerte, que es una forma de la vida, en tanto que aquí se encomian sus excelencias en el arte, que es una forma del amor. (50:157)

Un año antes de la susodicha velada, es decir, en x875, comentó Martí los temas de la poesía, la belleza y la presencia del sentimiento en el arte:

Yo creo que todos son poetas, y que [Pedro] Castera lo ha sido porque hubo algo poderoso que despertó en él lo que llamo universal y común fuerza de poesía. La poesía no es más que la forma agradable de la belleza, y el sentimiento de lo bello, vive en el mismo sentimiento, belleza suma. (50:26)

Pero, a diferencia de Nájera, Martí puso límites a la consecución de lo bello, reflejando así la dimensión heroica y revolucionaria de su vida, y, a la vez, la medida en que ésta moldeó sus ideas estéticas. En uno de muchos artículos sobre el teatro mexicano insistió sobre la necesidad de fomentar las actividades literarias nacionales, afirmando que el teatro no es 
... solamente la presentación y desarrollo agradables de un pensamiento bello: han de llevar en sí el precepto bueno, no a manera de plática enojosa, ni de predicación cansada e infructífera. Está la moralidad en el correr de la acción: en atraer toda la simpatía sobre el noble... Que la belleza de la forma envuelva el buen precepto: que la alteza de los personajes envuelva el ejemplo bueno. (49:99)

A pesar de este venero práctico o pragmático que se patentiza en sus escritos teóricos, Martí no dejó de expresar su disconformidad con el positivismo: "Domina a buena parte de nuestra juventud una sistemática filosofía práctica, que tiene de errónea todo lo que tiene de sistema filosófico" (49:97). Como Nájera, tampoco sancionó una literatura materialista. De hecho, los dos iniciadores del modernismo se expresaron en lenguaje parecido sobre este tema. Nájera, anti-realista ${ }^{41}$ y anti-materialista, aboga por una literatura en consonancia con las exigencias de la vida americana:

Aquí, donde la naturaleza tiene su apoteosis, campo anchísimo se presenta a los ojos del poeta; en la soledad de nuestros vírgenes bosques, en nuestras selvas frondosas, bajo nuestro azul firmamento tachonado de resplandecientes luminares, no puede cantarse nada impuro, no puede rendirse culto a la materia; aquí sólo pueden resonar himnos a los sentimientos nobles del corazón humano, aquí sólo se puede rendir culto a la belleza. (Obras 1,63 )

Comentando la obra de Agustín F. Cuenca, "La cadena de hierro", ${ }^{42}$ Martí también defiende una doctrina de americanismo literatio, condenando doctrinas literarias enraizadas en el decadentismo europeo:

Hay genio de belleza y de grandeza, como hay crítica de envidia $y$ de lealtad. Un arroyo es bello, y un mar es bello, con su dis-

41 En 1890 en "La hija del rey' de José Peón y Contreras" modifica su posición: "...me gustan las novelas de Zola" (Obras I, 409).

42 Nájera comentó esta obra en el Correo Germánico del 31 de agosto, 2 de septiembre y 5 de septiembre de 1876 (Obras I, 133-142). Martí, en la Revista Universal, el 27 de agosto de 1876 (50:189-196). Nájera considera la obra "...un drama que está llamado a pasar a la posteridad y acaso a ser presentado más tarde por modelo ( $p .136$ ). Martí rechaza su exagerado realismo inspirado en modelos franceses, pero ve en el drama momentos de acierto artístico: "¿Es realista la obra de Cuenca? No, porque es falsa. ¿Es útil? Sí, porque es bella (50:192). 
tinta $\mathrm{e}$ independiente clase de hermosura. Cuenca tiene el genio de grandeza

Viva la vida ardiente de los hijos de la naturaleza americana: pinte pasiones sanas, refrésquese en amores puros, eduque su alto espíritu en la contemplación de la virtud. Los cadáveres no sirven más que para abono de la tierra; los engendros franceses, el bizantinismo moral, la imitación servil de un pueblo enfermo, no, convienen a una patria naciente, sin cauce ni guía fijo, que a la par habla co. rrectamente y balbucea, donde hay hombres pansofos y hombres bestias, donde hay pasiones primitivas y refinamientos de la pasión, donde en caótica mezcla, la cuna de los indios ha ingerido sus mimbres en los ligamentos del madero corrompido que a manera de sepulcro espera a una civilización cansada y decadente. (50:195) ${ }^{43}$

La alusión a las repulsivas creaciones de la escuela naturalista francesa es obvia en los comentarios de ambos y, los dos, no contentos con referencias indirectas, patentizan su aversión en formas más concretas. Nájera apostrofa:

¡Oh! no; en nuestra patria, aquí donde se rinde culto a todo lo bello y a todo lo grande, jamás podrá imperar la escuela realista, hija enfermiza de la prostituída Europa, nacida entre la embriaguez y locura de la orgía. La virgen América no dobla su cabeza al yugo de la carcomida Europa. Es bastante potente para levantarse muy alto por sí misma y crear una escuela propia. (Obras $I, 63$ )

El Maestro se horroriza igualmente ante "el bizantinismo moral" procedente de la Europa enferma:

La enseñanza de la virtud es más noble que el examen inútil de las hondas llagas sociales. Lamartine hará un ángel de una meretriz: Sandeau y Belot convertirían en meretriz a un ángel. ¿Qué placer digno, qué satisfacción gloriosa pudiera producir a un poeta

43 En 1876 Martí comenta "Los Maurel" de Roberto Esteva, y, conforme a su propósito de alentar el desarrolio del teatro nacional, incluye los siguientes comentarios sobre el teatro mexicano $(50: 180)$ : "El teatro ha de ser siempre, para valer y permanecer, el reflejo de la época en que se produce. ¿Es mexicana por completo la actual época de México? ¿Sin sociedad enteramente propia, puede haber teatro cómico propio que refleje un cuerpo que no existe?", 
noble la repugnante psicología, la inútil fisiología moral del vicio? ¿Se es mejor por saber la manera con que son malos los demás? $(50: 195-196){ }^{44}$

Contra la imitación - la imitación de lo material- se rebela Nájera en "El arte y el materialismo", llamando tal procedimiento "error monstruoso":

Si el único principio del arte fuera la imitación, un término supremo consistiría en la completa ilusión de los sentidos, y si tal fuese necesario, sería convenir en que el artista más sublime sería el espejo que con más fidelidad retratase los objetos. ¡Error monstruoso! (Obras $\left.1,5^{8}\right)$

Martí también se declara en contra del remedo, pero, de otro tipo-el literario- combinando el principio de arte autóctono y auténtico con el anhelo de una poesía nueva, producto de la fantasía liberada de las restricciones impuestas por las preceptivas ( 1876 ):

Puesto que tenemos voluntad, criterio e imaginación, sírvannos los tres: la imaginación para crear, el criterio para discernir y para reprimir la voluntad. Los hombres son todavía águilas caídas, y ha de haber alguna razón para que aun no se nos devuelvan nuestras alas.

Y luego, con ser siempre una en esencia la poesía, va siendo con las épocas múltiple en formas. Dejan los hombres culminantes, huellas sumamente peligrosas, por esa especie de solicitud misteriosa que tienen a la imitación. Polvo de huesos y sedimento de humus habrán sido ya muchas veces los restos de Anacreonte y de Virgilio, y aun hay en la expresión rimada del sentimiento poético, tintes de aquellos conceptos sentenciosos de los dos latinos. El estudio es un mérito; pero la imitación es un error; más que error, una dejación de la dignidad de la inteligencia... (50: II-I 2$)^{45}$

44 En 1875, al reseñar La esposa del vengador de Echegaray, Martí declaró su antipatía por las obras literarias de mera copia, entendiendo por "copia" la de la realidad fea: "la belleza es bastante poderosa por sí misma y es más bella de seguro que la copia de una probable fealdad" (51:98).

$45 \mathrm{~V}$. también de 1875 , este trozo alusivo al tema de la libertad artística: "Todo anda y se transforma, y los cuadros de vítgenes pasaron. Imagínese $y$ 
El espítitu renovador martiano se transparenta a continuación en el mismo escrito, cuando el poeta va más allá del rechazo de la influencia del naturalismo y del realismo e insiste sobre el fundamental principio de toda innovación literaria: la condena de las formas artísticas que se estilan en la época:

Es ley ya que termine la fatigosa poesía convencional, rimada con palabras siempre iguales que obligan a una semejanza enojosa en las ideas. No se hacen versos para que se parezcan a los de otros: se hacen porque se enciende en el poeta una llama de fulgor espléndido, y enardecido con su calor, allá brota en rimas en tanto que de su alma brota amor... La voluntad no debe preceder a la composición poética: ésta debe brotar, debe aprovecharse su momento, debe asírsela en el instante de la brotación; lo demás fuera sujetar e]. humo a formas. (50:12)

Entre algunos de los modernistas el arte como fenómeno divino y sagrado era una idea expresada y defendida con frecuencia. De Nájera es el pensamiento "...lo bello es... la revelación de Dios... lo bello tiene que ser necesariamente ontológico; es lo absoluto, es Dios. Dios que se revela en las sublimes creaciones del poeta, en las dulces melodías de la música, en los lienzos que con magnífico pincel traza el artista..." (Obras I, 55).46 No con fundamento religioso, como en el caso de Nájera, sino más bien espiritual, asentó Martí idéntico concepto entre 1875 y 1877 , expresándose con una imaginería modernista que revela la herencia romántica, en especial, la becqueriana: arpa, luz de oro, seno de colores, nubes:

El arte es la forma de lo divino, la revelación de lo extraordinario. La venganza que el hombre tomó al cielo por haberlo hecho hombre, arrebatándole los sonidos de su arpa, desentrañando con luz de oro el seno de colores de sus nubes. El ritmo de la poesía, el eco de la música, el éxtasis beatífico que produce en el ánimo la contemplación de un cuadro bello, la suave melancolia que se adue.

créese; que en todas épocas existe lo fantástico; pero no se ate la imaginación a épocas muertas, ni se obligue al pincel a mojarse en los colores del siglo xI y del XIV" (50:63).

46 V. también la última estrofa de "Non omnis moriar" (1893): "porque existe la Santa Poesía/y en ella irradias tú, mientras disperso/átomo de mi ser esconda el verso./ ino moriré del todo, amiga mía!" [Poesias completas (México: Porrúa, 1953), II, 302]. 
ña del espíritu después de estos contactos sobrehumanos, son vestimentos místicos, y apacibles augurios de un tiempo que será todo claridad. (55:16)

Este trozo, entresacado de un cuadernillo de apuntes de viajes por México, encierra un conjunto imaginístico (sonidos de su arpa, luz de oro, seno de colores) que revela, aunque en forma incipiente, el creciente interés de Martí en la unión y en la utilización artística de sentidos dispares: luz, color, sonido. La sinestesia suave melancolia parece confirmar la preocupación sincrética observada por el poeta en la obra de escritores europeos coevales cuyas ideas refleja Martí en este pronunciamiento teórico de 1876 :

Poetas, muisicos y pintores, son esencia igual en formas distintas: es su tarea traer a la tierra las armonías que vagan en el espacio de los cielos, y las concepciones impalpables que se agitan en los espacios del espíritu. Formalizan lo vago: hacen terreno lo divino. Es mejor el que más cantidad de cielo alcanza. (50:122-I23) (EI subrayado es mío)

En conceptos que no tienen par en las ideas najerianas de la época, Martí concibe el arte en términos sinestésicos (poetas, músicos y pintores, son esencia igual en formas distintas) y el artista como artesano que concretiza "lo vago", como recomendaba el poeta simbolista francés de Romances sans paroles. 47

Del mismo venero sincrético son las observaciones siguientes, en consonancia con los cánones teóricos modernistas, y escritos en I875, después de visitar una exposición de la Academia de San Carlos en el primer caso, y en el segundo, tras la lectura de la obra de Pedro Castera:

El color tiene más cambiantes que la palabra, así como en la gradación de las expresiones de la belleza, el sonido tiene más variantes que el color. Como la belleza es la conformidad del espíritu con todo lo indescifrable, lo exquisito, lo inmedible y lo vago, lo bello se expresa mejor en tanto que tiene más extensión en que expresarse, menos trabas para producirse, más medios con que reflejar la abstracta necesidad, la mórbida concepción, las combina-

47 Sobre lo verleniano en Martí y. Manuel Pedro González, "Conciencia y voluntad de estilo en Martí", pp. 199-201. 
ciones tempestuosas o apacibles de esta presunción de lo venidero, religión de la soledad, propio hogar del hombre, que llaman caprichosa fantasía. (50:59)

$$
\text { * * * }
$$

La música es más bella que la poesía porque las notas son menos limitadas que las rimas: la nota tiene el sonido, y el eco grave, y el eco lánguido conque se pierde en el espacio: el verso es uno, es seco, es solo: -alma comprimida-forma implacable-ritmo tenacísimo.

La poesía es lo vago; es más bello lo que de ella se aspira que lo que ella es en si. (50:23-24)

En estos trozos se itera el principio de la vaguedad verleniana notada arriba y, además se revela la afición martiana por los efectos sonoros y el arte musical - todo en fecha muy temprana dentro de la cronología modernista: I875. En efecto, Martí fue un gran admirador y un profundo conocedor de la música, cuyo poder arrobador evoca en estructuras neoplatónicas (1875):

Hay una lengua espléndida, que vibra en las cuerdas de la melodía y se habla con los movimientos del corazón: es como una promesa de ventura, como una vislumbre de certeza, como prenda de claridad y plenitud. El color tiene límites: la palabra, labios: Ia miseria, cielo. Lo verdadero es lo que no termina: y la música está perpetuamente palpitando en el espacio. (I3:129)

Igualmente relevantes son las líneas de la misma crónica musical que venimos citando, en las cuales el éxtasis del cronista, al recordar los excelsos momentos del concierto del violinista White, se expresa en un estilo que transparenta una voluntad artística en la ordenación de los sintagmas no progresivos de ritmo variado $y$ de filiación ciceroniana: ${ }^{48}$

La música es la más bella forma de lo bello: -arrullar, adormecer, exaltar, gemir, llorar: el alma que se plega a un arco: el oído que se subyuga, se extasía, se encadena: este pobre ser; germen dormido, de súbito sacudido y despertado: esta revelación de lo más puro entre las lobregueces de la vida: esta garantía de lo eterno prometida al espíritu ansioso en el nombre augusto de lo bello:

$48 \mathrm{~V}$. como ejemplo de este aspecto del estilo martiano. las construcciones de El presidio político en Cuba, denominadas por lo general "biblicas". 
- tanto es ese lengua arrobadora, madre de bellezas, seno de ternuras, vaga como los sueños de las almas, gratísima y suave como un murmullo de libertad y redención. (I3:129)

Como Bécquer, Martí lucha por expresar el complejo emocional que lo avasalla, y busca, lo mismo que el vate sevillano, el modo de exteriorizar sus ideas en formas concretas: "Cómo han de querer mis palabras decir

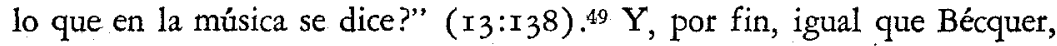
el prosista, sus palabras encuentran una construcción impresionista - la única capaz de traducir sus apasionados y vagos estados de alma:50

¿Qué era White tocando la música de Bach? Como dos fornidos luchadores se enlazan cuerpo a cuerpo, y se encarnizan en la lucha, y nada ven más que su exaltación creciente, y encendidos en ira no cesan en la fiera pelea hasta que el uno cae vencido, y se levanta el otro erguido vencedor. (I3:I38)

$$
* * *
$$

White no toca, - -subyuga: las notas resbalan en sus cuerdas, se quejan, se deslizan, lloran: suenan una tras otra como sonarían perlas cayendo. (I3:I3I) 51

Esta incipiente prosa artística - mejor dicho, una de muchas ilustraciones que se podrían aducir-52 escrita por el expatriado y joven cubano en una crónica en que también desarrolla, como hemos visto, sus ideas teóricas sobre la música, la pintura y la literatura, nos lleva a las consideraciones

49 De Bécquer (Rimas, I) son las versos:

$$
\begin{aligned}
& \text { Yo quisiera escribirlo, del hombre } \\
& \text { domando el rebelde, mezquino idioma, } \\
& \text { con palabras que fuesen a un tiempo } \\
& \text { suspiros y risas, colores y notas. }
\end{aligned}
$$

[Obras completas (Madrid: Aguilar, 1954), p. 439].

Darío, en 1901, en su soneto "Yo persigo una forma..." se quejará también de la insuficiencia lingüística: "Yo persigo una forma que no encuentra mi estilo, / botón de pensamiento que busca ser la rosa/... Y no hallo sino la palabra que huye, la iniciación melódica que de la flauta fluyel..." [Poesía (México: Fondo de Cultura Económica, 1952), pp. 246-247].

50 Para un análisis de las relaciones entre el éstilo de Bécqeur y el de Martí, v. nuestro estudio "Bécquer y Martí: coincidencias en su teoría literaria", Nueva Revista Cubana (1962), 3-26.

51 El temprano uso del impresionismo en Nájera está discutido en Símbolo y color en la obra de José Martí, p. 439, n. 39.

52 Para una discusión más completa, con ilustraciones, v. el estudio de Manuel Pedro González, "Conciencia y voluntad de estilo en Marti". 
estilísticas, a la plasmación en formas expresivas de la teoría najeriana y mattiana de este periodo formativo que estamos explorando.

\section{ESTILO}

En la sección anterior afirmamos que "El arte y el materialismo" de Nájera no evidenciaba mucha novedad en cuanto a las ideas teóricas. En cambio, hay en el escrito indicios de un naciente estilo imaginístico de filiación modernista cuya importancia se ha descuidado. ${ }^{53}$

Hace poco, al comentar un escrito martiano de I875, aludimos a sus construcciones neoplatónicas; en "El arte y el materialismo" las hay también, y cuajadas de imágenes ascensionales:

$\mathrm{Y}$ ese principio que defendimos, es el santo, el sublime principio de la libertad ... sin la cual el arte, sin poder alzar su vigoroso y atrevido vtelo, sujetas sus alas por la férrea cadena de la esclavitud, anhelando en vano sacudir su yugo y lanzarse en pos de las regio. nes de la luz y de la vida, mancha la blancura nítida de sus alas con el cieno de la tierra, y contemplando sólo los repugnantes cuadros que el mundo le presenta, cae en la profunda y tenebrosa sima del más terrible materialismo. (Obras $I, 52.53$ ) (El subrayado es mio)

En éste, como en otros artículos de la época, ${ }^{54}$ Nájera insiste sobre el uso de vocablos e imágenes idealistas: alzar, vuelo, alas, regiones de la luz, blancura, contrastando estos términos empíreos con los de valor polar (cieno, yugo, sima). ${ }^{55} \mathrm{El}$ conjunto de lenguaje figurado se enriquece con otros tropos:

...así el espiritu corre sin descanso tras de esas mariposas de la mente que se llaman ideas... (Obras $I, 58)$

$$
\text { *** } *
$$

Ese no es ni puede ser el arte; no es el águila altanera que alza su potente vuelo en la llanura; es la rastrera serpiente que se arrastra por el lodo... (Obras $I, 6 \mathrm{r}$ )

$$
* * *
$$

53. Carter en su artículo polémico sólo discute el uso del símbolo ave (p. 304, n. 26).

54 V. por ejemplo "Páginas sueltas', de Agapito Silva" (Obras I, 109-127).

55 Sobre el empleo de la técnica antitética v. la sección intitulada "Polaridad" (pp. 82-94) de nuestro libro Símbolo y color en la obra de José Martí. 
... déjese al poeta levantar su espiritu del sucio fango de la tierra, déjesele volar libremente en alas de su imaginación por los celestes espacios del idealismo, cernerse como el águila en las ondas purísimas del éter, y soñar con mundos de luz y de ventura, con ángeles de amor y de belleza. (Obras I, III-II2)

\section{***}

Como aquella mistica ascensión del gran poeta de los siglos medios, el inmortal cantor del dogma católico, cada vez que llegamos a una de las mesetas de esa altísima montaña, dejamos una flaqueza del cuerpo, una mancha del espíritu, y lentamente el horizonte se va ensanchando; la luz que primero se anuncia en pálidos albores ...y por último, cuando después de haber sacudido toda la existencia grosera y mundana se llega a la deseada cumbre, entonces, como el perfume de una flor que por los hilos conductores marca el rayo del sol, se lanza con vuelo eléctrico a buscar el imán que lo atrae en el infinito... (Obras I, IIg-Ir6) ${ }^{56}$ (El subrayado es mío)

Las arriba subrayadas imágenes elevacionales -estructura espacial que revela la proyección del artista al mundo real ${ }^{57}$ son comunes a la obra de Martí y Nájera y patentizan las coincidencias de ambos en la creación de una expresión imaginística. En los escritos martianos, como en los de Nájera, aparecen las formas tropológicas de filiación idealista durante los mismos años: I875-1877. En I875 opinaba Martí que el drama de Echegaray tenía

... esa nebulosidad y esas alturas en que se sienten bien ... los espíritus que de lo hondo y limitado de la tierra ascienden por extraña fuerza propia a esferas de presentimiento y de creación ... Cuando el águila extiende sus alas, se alza en sí misma, se alza a lo alto, desgarra con sus pies la superficie de la tierra. Aguila es un espíritu noble: vuela como ella una inteligencia ardiente y soñadora: sean, pues, entendidos y apreciados los afectos del drama de Echegaray. $(47: 100){ }^{58}$

56 Además de los símbolos empíreos, asociados con una construcción dinámica, y reveladora de cualidades idealistas, debe mencionarse el hecho significativo de que Nájera, en 1876 emplea el cisne en "Siempre a ti", aunque con valor tradicional del ave que canta, moribundo, antes de emprender el viaje final a la ultratumba: "mi alma expira en los brazos del martirio, / y canta, como él cisne su amargura" [Poesías completas (México: Porrúa, 1953); I, 111].

57 Sobre esta manera de interpretar los textos literarios, v. Théophil Spoerri, "Eléments d'une critique constructive", Trivium, VIII (1950), p. 167.

58 Para otras ilustraciones de águila v. José Mattí, Apuntes inéditos (La Ha- 
La misma nota de elevación, de nebulosidad, la búsqueda de las alturas "en que [los espíritus] se sienten bien", amén del uso de la imagen águila, se nota en este trozo, como en los anteriores de la pluma de "El Duque". Veamos otras ilustraciones de Martí que, entre 1875 y $\mathbf{1 8 7 7}$, evidencian un lenguaje figurado que solemos asociar con la estilística modernista, sobre todo en prosa. En los dos primeros ejemplos que a continuación ofrecemos, nótense los sintagmas no progresivos y la ordenación paralelística - diríase geométrica- de las cláusulas:

Porque el peso se ha hecho para algo: para llevarlo;

porque el sacrificio se ha hecho para merecerlo;

(I876) porque el derecho de verter luz no se adquiere sino consumiéndose en el fuego. (50:17) 59

Hay en el alma como otro ser dormido, fiera cuando lo mueve al espanto o a la venganza, llanto cuando lo agita

( 876 ) el duelo o el amor. Ora es melancolía insensata: ora es ave oprimida que nos rompe el pecho con el mover inquieto de sus alas. (50:1 13 )

$$
\text { * * * }
$$

Ahoga la vida diaria politica a los que dotó la naturaleza de miras elevadas: habitúase el ánimo con el contacto a las cosas personales y pequeñas: adormécese el ingenio, el mismo genio se adormece por falta de cultivo y desarrollo...

Bate el ave las alas en la región poblada por los

(1875) aires: ¿dónde las bate esta pobre ave herida, aletargada en el fondo de cada inteligencia pensadora y de cada noble corazón? (49:27-28) ${ }^{60}$ (El subrayado es mío)

En esta crestomatía de citas martianas sólo hemos tocado una parte mínima del lenguaje figurado correspondiente a esta época, omitiendo el empleo de imágenes como caballo, corcel, estrella, rosa, flor, paloma,

bana: Publicaciones del Archivo Nacional de Cuba, 1951), p. 7; 50:11.12 y 68:12, donde se usa el tropo compuesto, emblema de la vida artística frustrada del modernista - águila enferma: "...los que sienten la naturaleza tienen el deber de amarla; las alboradas y las puestas son el verdadero estudio de un artista; un pintor en su gabinete es un águila enferma".

59 V. $42: 42 ; 50: 23,51: 84$ para otros ejemplos de luz.

60 V. 55:75 y 42:131 para otros ejemplos de alas. 
ópalo,61 limitación impuesta por el propósito de ceñinos a las coincidencias estilísticas de los dos escritores.

En el trienio que estudiamos, Nájera y Marti utilizan tropos que pertenecen a la tradición cultural grecolatina, algunos de los cuales fueron incorporados en fecha posterior a la imaginería modernista. Ambos prefieren las metáforas de signo idealista, las cuales, con frecuencia, contrastan con otras de sentido polar, sugiriendo así las dualidades de la existencia humana. En Nájera (seis años menor que Martí) predominan, todavía por estas calendas, las formulaciones y contextos románticos; ambos, sin embargo, emplean embrionarias construcciones impresionistas o simbólicas que más tarde constituirán innovadores aspectos de su estilística.

Las novedades cromáticas son más aparentes y significativas en este período; Nájera y Martí lograron aplicar al lenguaje literario hispánico los procedimientos técnicos pertenecientes a otras disciplinas artísticas, a saber, la escultura, la pintura y el aguafuerte. Siguiendo el ejemplo de los parnasianos y de los simbolistas, crearon páginas de estilo cromático utilizando la sinestesia, la catacresis, la hipálage y la bisemia. De Martí es el enunciado teórico, citado arriba en su totalidad, "el color tiene más cambiantes que la palabra..." (50:59) que expresa, ya en 1875, la preocupación de los modernistas por introducir en formas literarias los efectos cromológicos. La policromática paleta martiana se reduce, en los años que nos ocupan, al amarillo, al azul,62 al celeste, al blanco, al negro y al oro; con estos colores crea Martí estructuras artísticas de subido valor, como se verá en las citas que a continuación of recemos, ordenadas cronológicamente dentro de cada color para que se vea el desarrollo de este relevante ingrediente estilístico:

$A z u L$

(1875) Tiene una imagen amadísima, y en todo ve copia de su imagen: ama lo azul, porque lo azul ... da idea poética del exquisito espíritu por quien siente amor tan alto, que

61 V. Simbolo y color en la obra de José Martí para una discusión de estos tropos.

62 Sobre el azul, el profesor Carter, en el ya aludido artículo crítico de nuestras ideas, se limita a comentar tres citas, si bien confiesa que "puede haber otro [ejemplo] que no hayamos podido notar" (p. 298) - cosa extraña puesto que las páginas $471-480$ de Símbolo y color... y las correspondientes notas contienen todos los necesarios datos para el lector acucioso. El mismo volumen contiene un análisis del cromatismo martiano (pp. 444-520). 
sólo tiene semejante en su varonil resignación y en su respeto. (50:24)

(1875) Está muy lejos el azul soñado. (42:98)

(I875) ¿Por sueño?...

$¡$ El alma enamora!

¿Por encanto?...

¡Azul parece! (26:186)

(I875) Nada es azul en la vida (26:I9I)

(1875) ¡Leonor, mi amada Leonor,

Cómo más presto me hablaras,

Si en el alma me miraras

El lago azul de tu amor! (26:192)

(1876) Y preparados ya a lo inmenso por ese cielo elocuente mexicano, que parece una azul sucesión sin término de cielos, le habría yo inspirado la manera de acostarse, cielo y hombre, por la tranquilidad, que es una gran osadía, en un mismo lecho. (50:18)

(1876) Si alguna fantasía potente vuelve a sí las miradas descontentas de la vida, ¿qué azul no reflejará en los versos el cielo inmaculado del seductor valle de México?

( 1876 ) Pero hay entidades poéticas, cantores de lo venidero, arúspices divinos de una religión vasta y azul. (50:I70 I I I )

Celeste

(1876) ... tal podría decirse que todos los poetas españoles habían besado a las mujeres en la boca, y que fue Ruiz de Alarcón el primero que supo que podía besárseles la frente. Así impregnada de casta tenuidad, es la mujer celeste de Alarcón. (50:162)

(I877) Un espíritu celeste, el de mi amorosa criatura, me ha dado brío secreto para quebrantar en bien de todas estas, para nadie útiles, ligaduras: ¿qué habrá erróneo que nazca en su espíritu altísimo y perfecto? (68:19) 
Hemos descartado las ilustraciones cromáticas pertenecientes al período 1875-1877 en que el azul se usa en formulaciones puramente miméticas, incluyendo sólo las encarnaciones en que el color cerúleo indica un plano real de idealidad, de ensueño, perfección, belleza y excelsitud $-\mathrm{y}$, en construcciones cromáticas bisémicas, sinestésicas e hipalágicas tan prodigadas por los artistas del modernismo.

Nájera, en este periodo, también se sirve del azul:63

(I876) el ropaje azul del firmamento.64

(1876) Es blanca tu conciencia y azul tu pensamiento (P.C.:I, 108) 65

(1876) aire azul (P.C.:II, 314)

(I877) bordar con perlas el azul del cielo (P.C.:I, 40)

A estos ejemplos debemos agregar el que el Profesor Carter aduce en su ensayo polémico66 -el único que data de I875 ("Serenata"):

Si en la noche callada

la blanca luna

riela en la onda azulada

de la laguna

por tí suspiro,

que en el fondo del agua

tu imagen miro.

(P.C.:I, 82)

63 El profesor Carter reproduce un poema de 1874 publicado en El Búcaro en que Nájera utiliza la imagen "bóveda azul" ("Gutiérrez Nájera y Martí como iniciadores del modernismo", p. 299). Como no tiene relación alguna con la estilística modernista, no lo comentamos.

64 Poesias completas (México: Porrúa, 1953), I, 31. En adelante usaremos una forma abreviada dentro del texto para referirnos a esta edición: (P.C.:I, $3 i$ ),

65 En 1877 dirá: "Más blanca que su rostro es su conciencia" [Cuentos completos (México: Fondo de Cultura Económica, 1958), p. 376].

66 P. 298. El profesor Carter comenta este poema romántico (p. 299): "No hay que esforzar la imaginación para ver en esta estrofa la simbólica unidad de 'tu imagen' (por la que suspira el poeta) con el color del agua en el fondo de la laguna". Reputamos una sutileza exegética, sin base real, esta equiparación simbólica de imagen y agua, $y$ aún más aventurada la insistencia sobre el color azul del fondo de la laguna con el color de la ola. No se trata, a nuestro entender, de una construcción sinestésica - ni real ni intencionada. 
De estas citas najerianas la única que revela conciencia artística renovadora, y, el conocimiento de las correspondencias de Baudelaire, de los escultórıcos y cromáticos experimentos de Gautier, y de "Voyelles" de Rimbaud es la del 76: "Es blanca tu conciencia y azul tu pensamiento". La imagen "aire azul" es visual y mimética, o, cuando más, reviste un valor hipalágico, como puede observarse por la cita completa:

Que al extender su manto la tenebrosa noche, Cuando los astros vieron su deșmayada luz, se ve que poco a poco cerrando vas tu broche y mustio y soñoliento te aduerme el aire azul.

En cambio, en las citas de Martí arriba reproducidas, encontramos varias encarnaciones que pueden identificarse de modo completo con la estilística modernista: el azul soñado, nada es azul en la vida, el lago azul de tu amor, azul sucesión, religión azul. ${ }^{67}$

Veamos ahora el caso del color blanco, el segundo de los únicos dos colores discutidos por el profesor Carter en su artículo sobre los dos iniciadores del modernismo. En este estudio Carter cita ejemplos del uso que hace Nájera del blanco en los siguientes poemas: "Ven a mi gruta" (1876); "Serenata" (I875); "Luz y sombra" ( 1876$)$; "Mi casa blanca" (1877); "Albores primaverales" ( I877); y, "Amor y muerte" ( I876), composición sobre cuya paternidad tiene sus dudas el profesor Carter. ${ }^{68}$ A estos títulos habría que añadir "Un drama en la sombra", cuento del 77 en que Nájera se sirve de la catacresis; "Más blanca que su rostro es su conciencia"; 69 "Amor de niño" ( 1877 ): "tal es la página blanca de mi tranquilo pasado" (P.C.:I, II7); "blanca brisa perfumada" del poema

67 Respecto al azul modernista, es significativo el poema de Antonio F. Grilo "Tu traje azul" que Carter reproduce en su estudio polémico ( $p .299)$. Es dudoso, sin embargo, que el azul modernista proceda de este poema becqueriano y romántico, y más dudosa aún la idea de que el primero que usó el azul en un sentido modernista es "el iniciador" del modernismo. El modernismo es mucho más que los valores cromáticos, y el azul sólo uno de los muchos colores que los modernistas empleaton con sentido simbólico. El modernismo, en contestación a la pregunta que plantea Carter en la página 309, es toda una época de revaloración, transformación y reforma: Juan Ramón Jiménez en El modernismo; notas de un curso (1953) (México: Aguilar, 1962) dice que "todo cae dentro del modernismo porque todo es expresión en busca de algo nuevo hacia el futuro" (p. 229).

68 En torno a Gutiérrez Nájera y las letras mexicanas del siglo XIX (México: Botas, 1960), p. 153 .

69 Cuentos completos, p. 376. En adelante utilizaremos una forma abreviada dentro del texto para referimos a esta edición: (C.C., 376). 
"Del libro de Lola" (1877), (P.C.:I, I45). De todos los títulos aducidos por el doctor Carter sólo la siguiente encarnación es de relevancia, por la voluntad artística y la conciencia del valor simbólico del color que revela: blanca conciencia (1876). La "blanca casita", de tono y contexto románticos, por la aplicación de la técnica bisémica, sugiere la pura e intachable ilusión amorosa del poeta. Pertenece al mismo venero estilístico "la página blanca", que el poeta relaciona con "amores castos" y "tranquilo pasado". El sintagma catacréstico "más blanca que su rostro es su conciencia" es una variante de la formulación más sintética "es blanca tu conciencia", ya citada, de "Luz y sombra", y, por fin, "la blanca brisa perfumada", de filiación romántica, es una hipálage sugerida por "fuente" y "alborada", pero carente de novedad imaginística.

En la obra de Martí, escrita entre 1875 y 1877 , encontramos las siguientes construcciones "blancas", reveladoras del arte modernista:

Blanco Y lleva siempre en la plegada boca

Prendido el beso blanco que deseo. (42:97)

Es ella blanca y rubia como allá en las locuras escondidas se imaginan el candor $y$ la pureza. $Y$ vestía, sin embargo, de negro aquella purísima alma blanca. (49:90)

... los viejos suizos, amigos y camaradas de los Alpes, mueren con los ojos azules y con el color sonrosado en las mejillas, porque no han doblado en un siglo el tamo de roble en que se apoyan, ni su conciencia pura, blanca como sus neveros, - su báculo más fuerte. ( $\left.55: 1_{4}\right)$

Pilar Belaval, cuando con rara inteligencia unía a la altivez y ceño de una dama, el donaire y peculiar gracejo de las hijas de aquella Andalucía, tierra amada por el Sol, madre de flores y mujeres bellas, donde las blancas casas de los pueblos como que dan idea agradable de las blancas almas de sus hijas. (50:115) 
$\mathrm{Y}$, por fin, este ejercicio en blanco y negro, imaginístico e impresionista, escrito a Manuel A. Mercado con motivo de la boda próxima de Martí con Carmen Zayas Bazán:

Esta pasión tiene de indomable que es justa.--Se mide por la que la inspira y el que la siente. Será tal vez una ave blanca que cruce por el aire sin ser vista: pero perderá uno su blancura porque no lo vean? Aquí o allá, se será blanco.- Si yo no me casara ahora con Carmen, no tendria que preguntar a los cuervos para qué tienen las alas negras:-las extenderían sobre mí, y yo lo sabría. -Es cosa extraordinaria. $(68: 40)$

En la obra najeriana, entre 1875 y 1877 , es decir, entre los escritos cuya fecha de composición está precisada, no hemos podido hallar ilustraciones de otros matices -amén del azul y el blanco-- en función catecréstica o hipalágica. El negro aparece con frecuencia, pero con el significado tradicional de dolor, sufrimiento, tragedia, pesimismo, muerte, $y$, sin innovación expresiva:

Mi vida es un suspiro, tu vida una sonrisa:

Mi alma negra sombra, la tuya blanca luz. (P.C.:I, I08)

Martí también utiliza el negro; ${ }^{70}$ pero de mayor importancia para la historia del modernismo es su empleo del oro a partir de 1875:

Oro (1875)

(1875) A su lado trabajaba Ponciana Arriaga, hijo del hombre ilustre que incrustó principios de oro en la hermosa Constitución mexicana. (49:I62)

(1876) México les parece [a los vecinos] un pais de oro, y todo les sorprende en nosotros: nuestra historia, nuestras revoluciones; nuestras riquezas, $\tan \mathrm{mal}$ aprovechadas; nuestras minas que no cuidamos; nuestras poblaciones de tem-

70 V. Símbolo y' color..., pp. 486-488. 
porada, que no embellecemos; nuestros tipos y vestidos originales, ${ }^{71}$ que hieren vivamente su atención. (50:83)

(1877) De manera que, sin haberlo pensado, me encontré yo con que anhelaba gallardas aventuras, misteriosos encuentros, noches de oro y de abismo, sorpresas de fieras... $(55: 54)^{72}$

Aunque el oro aparece ya en 1868 en una composición dedicada por Martí al recién muerto hijo de Rafael María de Mendive,73 no es hasta 1875 cuando adquiere fijeza con el sentido de refinamiento, elegancia y excelencia moral y attística.

Asociado al oro, pero de valor antitético, por lo general, es el amarillo, matiz que se patentiza en 1876 con el significado de decadencia, muerte, melancolía o impureza moral. No se encuentra este color en formulaciones catacrésticas de sinestesias abstractas; cobra valor simbólico más bien por reiteración y bisemia. En los versos que a continuación reproducimos, los "signos de sugestión" - pálidos, se acongoja, se entumece, tierra belada, árbol moribundo- esbozan el plano real de amarillo:

Mas ¿cómo no te dueles,

¡Oh poetiza gentil! de que en extraña

Tierra enemiga te ornen los laureles

Amarillos y pálidos de España

Allá [en España], Rosario, el alma se açongoja,

El cuerpo se entumece

Cubre la tierra helada la amarilla

Veste que el árbol moribundo arroja $(42: \operatorname{III} 5 ;$ II 8$)$

De mayor significación dentro de la estilística modernista son las líneas

71 Manuel Pedro González en su "Conciencia y voluntad de estilo en Martí", p. 203 señala la importancia de este pasaje.

72 V. también 55:73.

Algo bello, algo tan suave

Como las nubes de oro 
siguientes que forman parte de unas notas sueltas, escritas sin propósito de publicarse, camino de Guatemala en 1877 :

No discurren por las calles esos gentiles suramericanos, hercúleos y apolíneos, del campo-y si, comidos por el alma excesiva, y amezquinados por la vida rápida en la ciudad, —ardientes y pequeños como griegos. Amarilla es la calle, - amarillas las casas, amarillo, con la puesta del sol —digna del pincel melodioso de Swain Gifford, -el vasto horizonte, amarillas escuálidas las gentes. No con ese noble bronce, color naturalísimo del cuerpo que ostentan almas templadas a buen fuego, - - sino con ese terroso matiz que acusa descuidada infancia, ascendencia oblicua, mente desocupada, sedentaria vida. (55:165-166)

Estas frases apuntadas con rapidez presentan un cuadro - nótese la sinestesia "pincel melodioso" - plástico e impresionista de la desfavorable concepción recibida por Martí de la calcinada isla de Curazao. Las escenas de la naturaleza, como ésta, en el período que estudiamos, con frecuencia suscitan' en Martí construcciones impresionistas, reflejo quizá del principio impresionista de pintar al aire libre sin las trabas impuestas por el arte académico y de salón. Los impresionistas "took painting out of the studio, stripped it of conventions (not however, all conventions, as [Charles] Ephrussi wrote), put it face to face with nature, tried to catch the honest sensation, however strange it might seem, bathed in an atmosphere and light always chainging"74. Dentro de este concepto del arte están las líneas que a continuación citamos de la obra martiana; el prosista se encuentra frente a un paisaje que desfila ante sus ojos y capta sus formas y colores con frases ligeras y notas aisladas: ${ }^{75}$

Al salir de Esperanza; en lo alto de la sombra de un cerro, un golpe de oro que verdea, que negrea, que amarillea de nuevo, que se entra por el bosque oscuro, corona del cerro inmediato. (55:2r)

Estas sentencias apuntadas rápidamente en un viaje a Veracruz en 1876

74 Wylie Sypher, Rococo to Cubism in Art and Literature (Nueva York: Vintage Books, 1963), p. 172.

75 V. Ia definición dé Fernando Lázaro Carreter del impresionismo: "Los escritores impresionistas... describen, no las cosas, sino las sensaciones de las cosas ... describir un todo con notas aisladas que impresionan al escritor..." [Diccionario de términos filológicos (Madrid: Gredos, 1953), pp. 187-188]. 
son pinceladas cromáticas, manchas descriptivas; Martí concretiza sus impresiones en los verbos verdea, negrea, amarillea, $y$, en los sustantivos sombra, golpe de oro, corona.

La imagen impresionista "vers à couleurs" en las líneas siguientes, escritas en francés, traduce en términos cromáticos el placer del poeta al contemplar la naturaleza centroamericana en un viaje por la región:

-Les dimanches, et le jour de la Vierge, sil'on regarde de loin le Cerro del Carmen, on croirait voir un entassement pittoresque de vers à couleurs, qui se meuvent paresseusement. Ces jours là, la colline est pleine des $[s i c]$ femmes... $(55: 97)^{76}$

La paleta martiana se enriquece con colores adicionales al correr de los años; su estilo se afina con una variedad de construcciones cromáticas -simbólicas, impresionistas, expresionistas, antitéticas. Las citas aducidas, pertenecientes a la época formativa entre el 75 y el 77 demuestran que ambos artistas, Martí y Nájera, utilizaron colores y técnicas en común, aunque Martí, de mayor edad y madurez que Nájera y, por supuesto, más genial, se adelantó en el empleo de algunos matices como el amarillo y el oro, y, en el uso consciente y artístico de la técnica impresionista, a partir de $1875 .{ }^{77}$

En la obra de Nájera hasta I88r, las construcciones impresionistas son del venero que Elisa Richter apellida "la forma primaria y virginal del hablar humano. Las primeras exteriorizaciones fueron... elementales reproducciones de una impresión". ${ }^{78}$ Las del "Duque" revisten la siguiente forma:

(188r) Alto, escueto, avellanado, frío, de manos secas y huesosas, una especie de eucaliptus animado... (C.C., 70)

(188I) ...el azul de cielo proyectaba una mancha azul en el centro del manantial. Los juncos han crecido, los nenúfares dilatan sus redondas hojas. (C.C., 73)

$76 \mathrm{~V}$. otros ejemplos del impresionismo martiano de este período en el ya citado estudio de Manuel pedro González "Conciencia y voluntad de estilo en Marti".'.

77 V. supra la cita sobre el violinista White. Sobre este particular v. también González, op. cit., pp. 206-207; 209-211; 214-216.

78 "Impresionismo, expresionismo y gramática", en El impresionismo en el lengraje (Buenos Aires: Imprenta de la Universidad de Buenos Aires, 1936), p. 72. 
(I88I) Sí, aquel París fangoso es el triunfo de la mujer, que, toda agilidad y luz, cruza las calles.... (C.C., 82)

En estas formulaciones elementales, sin asomo de novedad artística, hay una notable excepción en un escrito de 1876 intitulado "Páginas sueltas', de Agapito Silva'. En este ensayo crítico, lleno de imágenes, caracterizado por la emoción lírica, la prosa najeriana alcanza una tensión que se vierte en párrafos de verbalismo pictórico:

¡Alemania! Cuna de los héroes y los genios, madre del saber y de la ciencia, tierra clásica de la tradición, Alemania se presenta a nuestros ojos ceñida de altísimas montañas cuyas cimas se pierden orgullosas en el cielo, rodeada de umbrosos bosques oreados por el viento de los siglos, y bañada por las oscuras y verdosas ondas del Océano; Alemania se presenta a nuestra vista como el tálamo nupcial de la naturaleza y el espíritu. $Y$ allí, bajo las bóvedas altivas formadas por árboles colosales, discurría un pueblo nómade y salvaje, cuya cuna era un carro de guerra, y cuyo patrimonio consistía en la espada y el escudo... (Obras I, I I8) (El subrayado es mío)

$$
\text { *** } *
$$

No es el lied la expresión del dolor salvaje y desesperado de lord Byron; no expresa tampoco la esperanza ardiente del Petrarca... No es la oscura y tenebrosa noche, iluminada sólo por la rojiza luz del rayo; no es el encapotado cielo en cuyo espacio no vierte su pálido fulgor ninguna estrella; es la melancólica noche iluminada por la luz poética y suave de la luna ... al escucharle creemos oír al viento susurrando en los bosques seculares... (Obras I, I I7-II8)

Las palabras subrayadas sugieren la fuente pictórica de esta expresión literaria. En el mismo ensayo leemos un pensamiento que parece confirmar el origen de este venero estilístico en la plástica: "El lied alemán no trae a nuestra imaginación estos risueños cuadros de campestres placeres . .." (Obras I, I22; el segundo subrayado es mío). Si a estos conceptos de la descripción como extensión de las técnicas del pintor se agregan algunas frases aisladas de "El arte y el materialismo", 79 se verá que Nájera, lo mismo que Martí vislumbraba - quizá sería mejor decir que intuía como posibilidad vaga - una forma literaria sincrética que uniera las técnicas

79 V. por ejemplo: "iLuz, color, vida! ¡Toda la paleta del pintor y todo el genio del artista, pueden emplearse en la imitación de tantos seres y objetos, y en la expresión de la Omnipotencia divina! (Obras $I$, 59). 
literaria y pictórica. Sin embargo, el "Duque", en esta época, nunca logró dar a estos pensamientos embrionarios las formulaciones teóricas que ya hemos visto en el Apóstol: v.g. "El color tiene más cambiantes que la palabra, así como en la gradación de las expresiones de la belleza, el sonido tiene más variantes que el color" (50:59).

Estas primicias del impresionismo literario plantean el problema de su origen, puesto que como técnica de la literatura el impresionismo no se difunde generalmente hasta después del 77 , cuando ya Zolá había publicado su novela Une page d'amour, une oeuvre demi-teinte (1878) ${ }^{80}$ y Alphonse Daudet Les rois en exil (1879), aunque anteriormente los hermanos Goncourt habían experimentado con este recurso expresivo, vago y sugeridor. En pintura, según Sypher, Manet dio a conocer al público su pintura revolucionaria Déjeuner sur l'berbe en $186_{3}$ en el Salon des Refusés, y, en 1869 Monet pintó su Femmes au jardin. ${ }^{81}$ Pero, no fue sino hasta 1874 , en la tienda parisiense del fotógrafo Nadar, cuando tuvo lugar la primera exposición de la pintura impresionista. Manuel Pedro González, en su "Conciencia y voluntad de estilo en Marti", 82 explica los primeros brotes impresionistas en la prosa martiana, apelando a la doble interpretación de la ascendencia de la pintura francesa (Martí estuvo en París en diciembre del 74) y la lectura de los Goncourt. ¿Y, Nájera? La influencia sobre él de los refinados estetas, autores del Journal, es plausible, tratándose de lector tan voraz como Nájera, sobre todo de las novedades francesas. ${ }^{83}$ Pero, también podría señalarse la herencia de la incipiente prosa artística de Bécquer, ${ }^{84}$ quien, a su vez, sufrió el influjo del pintor "luminista" Claude Lorrain. ${ }^{85}$ De hecho, cabe dentro de lo admisible que el ejemplo inspirador de las obras de los pintores que anhelaban expresar sus emociones vagas y líricas de modo original y buscaban un vehículo expresivo correspondiente-los del "genre pittoresque" y los "luministas", Claude, Gainsborough, Constable, Turner ${ }^{86}$

80 V. los comentarios sobre esta novela en Sypher, op. cit., p. 190.

81 Ibid., p. 169.

82 P. 207.

83 V. Margarita Gutiérrez Nájera, Reflejo, p. 157.

84 Sobre este tema v. nuestro estudio "Bécquer y Martí: coincidencias en su teoría literaria".

$85 \mathrm{~V}$. Edmund I. King, Gustavo Adolfo Bécquer: From Painter to Poet (México: Porrúa, 1953), pp. 76-78. King también señala afinidades del poeta español con Rembrandt y Murillo en cuanto al empleo de la luz en la prosa becqueriana (pp. 78-90).

86 Aunque estos pintores no exploraron de modo profundo las dimensiones expresivas alcanzadas por los impresionistas con el uso revolucionario de la luz y el color, indicando así una nueva concepción del espacio y el tiempo, habían 
con su capacidad para comunicar sentimientos en un paisaje- haya sido la fuente de sucesivas tentativas estilísticas que en la literatura y el arte desembocaron en el impresionismo. Y siendo Martí y Nájera conocedores del arte, no sería aventurado imaginar que ambos se conmovieron ante los hallazgos plásticos de los mencionados pintores y que sus novedades les orientó en su anhelo de remozar las formas literarias.

Darío, en su retrato de Martí, incluido en Los raros, sentenció que nadie "antes que Martí hizo admirar el secreto de las fuentes luminosas. Nunca la lengua nuestra tuvo mejores tintas, caprichos y bizarrías". ${ }^{87}$ Un trozo que forma parte de una crónica que Martí publicó en The Hour, ${ }^{88}$ en una fecha posterior ( 1880 ) al periodo que estudiamos, sugiere que las técnicas plásticas que fascinaban a los modernistas-la luz, el color, los matices, la luz contra la oscuridad, el brote repentino de la luz (nótense las palabras subrayadas de la cita abajo) - pudieran haber inspirado la aplicación a la literatura de lo observado en la pintura decimonónica:8s

They [las pinturas de Diaz] bear the imprint of his favorite effects of light, of which the most notable is a bit of blue sky, pure and limpid, in the midst of a dark canvas, whereof the thick forest and

dado el primer paso. Juan Ramón Jiménez (op. cit., p. 83), señala la importancia de Turner respecto al impresionismo.

87 Obras completas (Madrid: Mundo Latino, 1918), VI, 234.

88 Martí escribió en inglés unos ocho artículos (si los tenemos todos) en The Hour en 1880 , casi todos sobre pintura.

89 La devoción de Martí a la pintura y la escultura queda clara en la serie de crónicas escritas para The Hour a principios de la década del 80 , y, en otros escritos posteriores. De Nájera no poseemos toda la prosa, pero por estas líneas del 77 ("Mi inglés") se transparenta su conociniento de las artes plásticas:

En primer término y como presidiendo aquella aglomeración de obras maestras, veíase a Ticiano, el rey del colorido, aquel que tuvo por musa a una bacante y que ahogó su poesía, su sentimiento en la opulenta cabellera que caía como una lluvia de oro sobre la nívea espalda de su amada; a Giorgione, con la firmeza de sus líneas, la naturalidad y soltura de sus ropajes y el atrevimiento de sus toques; al Tintoretto, aquel que amaba el perfil de Miguel Angel y el colorido de Ticiano... (C.C., 13).

$Y$, en el trozo siguiente, su preocupación-igual a la de Martí- por el efecto decorativo y estético de la luz (1877):

Dos ventanas con vistas al jardín, cubiertas en parte por ligeras cortinas del mismo color de los tapices, veíanse entre un bosquecillo artificial de plantas exóticas y rarísimas flores, rodeadas por un hilo luminoso que a través de los opacos cristales se filtraba. Las alfombras, de un fondo aperlado con matices de rosa, completaban el elegante adorno. de aquel saloncillo. (C.C., 12-13). 
the water which reflects the dense foliage of the overhanging trees only serve to throw it into more vivid relief. Another autumnal sketch, filled with the subdued light of an October day, and a third picture, representing a woman recumbent on the grass ... are full of interest and artistic merit. The effect of light in the latter work, as it passes through a clearing in the opaque foliage and falls on the figure of the woman and of the little Cupid underneath, is really remarkable... the other [de Millet] whose inexhaustible beauties permit close inspection, is based on an effect of moonlight. A woman advances alone from a dark background, her back turned to the moon, which illumines the horizon with steady and sustained light. (52:99-100) (El subrayado es mío)

La plástica y la literatura están relacionadas en otro procedimiento estilístico, el último que consideraciones de espacio nos permitirán explorar en este ensayo: el parnasismo, modalidad expresiva en que lo sensorio, el color y la línea, tienen un valor trascendente. Frente a este arte refinado, impasible, plástico, Martí adoptó una doble y ambivalente actitud; de un lado rechazó la impasibilidad, la poesía marmórea de los seguidores de Gautier, y recomendó en su lugar la utilización de la emoción. Mas, por otro, no dejó de fascinarle esta expresión exquisita de formas esculpidas y perfectas. Aunque por lo general se asocia el parnasismo con el verso, en la obra de varios modernistas - Martí y Nájera entre ellos-aparece en su prosa, dándose así el fenómeno que llamamos "prosa de filiación parnasiana".

En la de Martí se funden rasgos parnasianos con construcciones impresionistas, produciéndose de este modo un estilo sincrético, como en la siguiente descripción de Orizaba, México, escrita en 1877:

Coronaban montañas fastuosas el pedregoso escirro y sombrío niblo; circundaban las nubes crestas rojas y se mecían como ópalos movibles; había en el cielo esmeraldas vastísimas azules, montes turquinos, rosados carmíneos, arranques bruscos de plata, desborde de los senos del color; sobre montes oscuros, cielos claros, y sobre cuestas tapizadas de violetas, atrebatadas ráfagas de oro. Gocé así la alborada, y después vino el sol a quitar casi todos sus encantos al paisaje, beso ardiente de hombre que interrumpia un despertar voluptuoso de mujer. El ópalo es más bello que el brillante. (68:12-I3) 
Este paisaje o "impresión" es todo un cuadro de medios tintes en que las manchas claras alternan con las oscuras como en los lienzos de los luministas; abundan los materiales nobles, aristocráticos y bellos de los parnasianos -esmeraldas, plata, ópalos-y las imágenes visuales y plásticas como cuestas tapizadas de violetas. El párrafo es una especie de kaleidoscopio, una sucesión de imágenes eminentemente parnasianas, pero, a la vez, impresionistas, agrupación imaginística que desemboca - como en el "género pintoresco"- - 90 en una expresión simbólica construida sobre las piedras preciosas, tan dilectas de los parnasianos: el ópalo y el brillante. El ópalo es para Martí símbolo de los aspectos morosos, dolorosos de la existencia, como se notará en las líneas siguientes, escritas también en I877:

Hoy andan de paseo las alegrías, y están tenazmente despiertas las tristezas.-Breve pues.--Mis amarguras son éstas de mi vida, que provienen precisamente de vivir. Si fueran piedra preciosa, serían ópalo. (68:34)

En la obra martiana las estructuras impresionistas revelan mayor desarrollo artístico antes de r882 - año clave en la maduración del estilo del Apóstol-que las parnasianas, aunque ya hemos notado que éstas se dan también, pero con más frecuencia, después del 80 . La formulación clásica del parnasismo de Martí aparece en 1885, en Amistad funesta:

La antesala era linda y pequeña, como que se tiene que ser pequeño para ser lindo. De unos tulipanes de cristal trenzado, suspendidos en un ramo del techo por un tubo oculto entre hojas de tulipán simuladas en bronce, caía sobre la mesa de ónix la claridad anaranjada y suave de la lámpara de luz eléctrica incandescente ... Linda era la antesala, pintado el techo con los bordes de guirnaldas de flores silvestres, las paredes cubiertas, en sus marcos de roble liso dorado, de cuadros de Madrazo y de Nittis, de Fortuny y de Pasini, grabados en Goupil; de dos en dos estaban colgados los cuadros, y entre cada dos grupos de ellos, un estantillo de ébano, lleno de libros, no más ancho que los cuadros... (25:37)

En la obra de Nájera, la estilística parnasiana apazece también antes

90 "Picturesque" dice W. Sypher en Rococo to Cubism "can be a kind of scenery giving pleasure to the eye or resembling painting, but it can also, and more creatively, be a way of projecting moods into scenery until landscape becomes a symbol" (p. 91 ). 
del 80, como revelan las líneas que a continuación citamos de "Mi inglés", cuento fechado en 1817, y que contiene una descripción muy parecida a la de Amistad funesta arriba citada:

Figuraos un vestíbulo amplio y bien dispuesto, con pavimento de exquisitos mármoles, y en cuyo centro derramaba perlas cristalinas un grifo colocado en una fuentecilla de alabastro. Pasad por alto los frescos y pinturas que adornan las paredes ... Nada hay, ni el más pequeño detalle, que no revele la opulencia y el gusto de Pembroke. En aquel jardín se han reunido, por un esfuerzo poderoso del dinero, los árboles y plantas de más extraños climas ... El floripondio de alabastro y el nenúfar de flexible tallo crecen al lado de la camelia aristocrática y del plebeyo nardo. (C.C., I2)

A pesar del parnasismo de este pasaje, el conjunto está impregnado de aquella característica del estilo najeriano que Justo Sierra, en el prólogo a la primera edición de las Poesías del "Duque", denominó "la gracia","91 cualidad que individualiza el estilo de este iniciador con toques aéreos, juguetones, y, a la vez, románticos. El cuento en cuestión, "Mi inglés", marca un hito en el desarrollo del estilo de Nájera, porque además del parnasismo arriba mencionado, contiene primigenios aspectos relevantes de su modalidad expresiva: el uso de palabras extranjeras — spleen, mail coach, gentleman, touriste, sotto voce, vendetta, parterre;'92 y la imaginería modernista en contextos de belleza y elegancia- " ${ }^{\circ}$ Oh! Alli la fantasía volaba como la mariposa, esa coqueta de la atmósfera, de los palacios moriscos de Giorgione a las Venus dormidas de Ticiano." (C.C., 9-1.4)

La técnica parnasiana se da en la prosa najeriana antes que en su poesía, por lo cual es idéntica en Martí y en Nájera la secuencia de la introducción de los procedimientos de Gautier.93 En poesía, el venero romántico del "Duque" diluyó la influencia del arte pulido y marmóreo de los parnasianos. No es sino en 1887 cuando aparece "De blanco", el ejercicio cromático, parnasiano y simbólico que con más fidelidad se aproxima al ideal de Le Parnasse. Es posible que el peso de la tradición, ${ }^{94}$

91 Citamos del prólogo de la segunda edición, Poesias (México: Librería de la Vda. de Ch. Bouret, 1897), I, 24.

92 En el mismo año, en "Al amor de la lumbre" aparecen las siguientes palabras foráneas: two miles, portière, sans façon, papier macbé. (C.C., 16 y 18).

93 En 1878, en una estructura de sinestesia cromática, Nájera menciona a Gautier: "¿Cómo me deleitaban aquel arte, aquella filigrana, aquella palabra colorida y pletórica de Theo!" (C.C., 21).

96 Enrique Anderson Imbert sugiere esta explicación en el caso de Rubén 
su temperamento romántico, y la concepción del verso como vehículo de la emoción íntima hayan demorado la incorporación de la estética parna. siana al verso de Nájera.

\section{CONCLUSIÓN}

De los dos iniciadores del modernismo, sólo hemos examinado una porción mínima de su producción, y de ésta la menos relevante desde el punto de vista del florecimiento de la estética y la estilística modernistas. Sin embargo, desde otro ángulo, el del principio y origen del modernismo como renovado estilo literario, los años entre 1875 y 1877 son de capital importancia, dado que con la llegada de la década del 80 las normas del modernismo están perfiladas en la prosa y la poesía de ambas figuras. En Martí, el año de 1882 es doblemente significativo, porque marca en la cronología de su estilo la fijeza de sus recursos expresivos en la prosa, y, en el verso, la publicación del Ismaelillo, que en el concepto de Federico de Onís inicia el modernismo en verso. ${ }^{95}$

Los cuentos de Nájera que integran su primer volumen publicado -Cuentos frágiles (1883) - remontan a 1877 , y a partir del ochenta, su estilo en prosa - y en verso- cobra fijación y madurez.

En este estudio hemos tratado de mostrar que el bardo mexicano y el apóstol cubano estrenaron estructuras y recursos estilísticos de naturaleza y alcance semejantes y de comparable novedad entre 1875 y I877. Martí era seis años mayor que Nájera en una época en que los años cuentan mucho en la madurez del individuo - entre los 16 y los 22 años; no es de sorprender, por lo tanto, que Martí se le anticipara a Nájera en el empleo de algunos procedimientos y en la formulación de ideas estéticas revolucionarias. Además, como sagazmente opinaba Juan Ramón Jíménez, Nájera estaba inmerso en el romanticismo ("LEs el primero de los americanos que expresa la transición del romanticismo al modernismo pero no es posible situarle dentro de éste ]") , ${ }^{96}$ y cuya herencia nunca abandonó del todo. Los atisbos de una estilística enraizada firmemente en la tradición hispánica clásica se vislumbran en los últimos años creadores del

Dario, en el prólogo a Rubén Dario, Poesia (México: Fondo de Cultura Económica, 1952), p, XIV.

95 Antología de la poesia española e bispanoamericana (Nueva York: Las Américas, 1961).

96 Op. cit., p. 69. Con la última afirmación no podemos estar de acuerdo. Gutiérrez Nájera, a pesar de su patente romanticismo - y su sentimentalismopertenece al modernismo. 
"Duque", tanto en su prosa como en su poesía. En prosa, por ejemplo, hasta los años cercanos a su muerte, cultivaba una modalidad que ya hemos definido como afrancesada, en que lo extranjero no está totalmente asimilado y expresado en un molde individual y original. En cambio, en I894, a modo de ilustración, leemos este párrafo cuya semejanza con la obra martiana en prosa es tan marcada que induce a pensar en una influencia Martí-Nájera:

Había nacido Luis Gonzaga para vivir en una de sus villas que parecen cestos de flores, que flotan en el agua azul y bullidora, rodeados de cisnes y ánades. Había nacido el apuesto caballero de Gonzaga para vivir la poesía, entre los magníficos vestidos de raso y terciopelo, con airosa toca cuyo joyel fuera un gran diamante. Había nacido para ser de la corte del príncipe Vitale ............

La poesía de Luis Gonzaga Ortiz es suave, meliflua, idílica y bucólica; sus mismas tristezas, sus mismas elegías, son caimientos de crepúsculo o añoranzas melancólicas. Es la de él, poesía que apacienta, que toca la zampona, que entrelaza los giros de la danza en fiestas de pastores y zagales; poesía que trasciende a tomillo y mejorana... A veces, sin embargo, sale de lo artificioso y lo convencional... Entonces zumba en ella, libando miel, el epigrama, o burila el verso, con aguja de oro, en mármol verde, el epitafio sobrio y penetrante. (Obras I, 529-530).

Esta es una prosa superada, en el sentido de que ya no pertenece a la variante expresiva afrancesada de los primeros años. Es, en cambio, una prosa vigorosa, cuajada de imágenes, a ratos impresionista, y siempre de la tradición hispánica que a la postre se impuso a pesar de los momentos afrancesados de los primeros años modernistas.

Al comparar estas dos figuras, hay que tomar en cuenta la dimensión ideológica de Martí. El mismo Nájera confesó su deuda para con el poeta cubano: "Me considero deudor a $\mathrm{U}$... de muchas ideas que ennoblecen mi espíritu y que me reconcilian con esquivos ideales". ${ }^{97}$ Sin ser un pensador sistemático - le faltaban la serenidad y el tiempo en su vida trajinada-Martí fue un hombre de ideas, las cuales en ocasiones le venían a la mente con tal abundancia que sólo encontraban plasmación en una

97 Margarita Gutiérrez Nájera, Reflejo, p. 153. 
forma estilística alambicada y barroca. Este venero ideológico, su refinado gusto estético, las nociones culturales adquiridas en edad temprana con Rafael María de Mendive, y su vida errante, iniciada antes de cumplir los diecisiete años, son los factores que ayudan a explicar la presencia en su obra, en época temprana, de ideas estéticas y estructuras estilísticas de pleno sentido renovador. La carencia de esta faceta ideológica no le resta importancia a Manuel Gutiérrez Nájera, como prosista, ni le quita el título de "iniciador" del modernismo en la faceta galicista arriba indicada. Si se desea fijarle una fecha determinada -0 un año-a la iniciación modernista, esa fecha es I882, año en que el modernismo, como teoría y como expresión literaria, aparece ya cuajado en la obra de Nájera y Martí. 98

En la polémica empezada por el profesor Carter, sirvanos de pauta la observación rubeniana de que cada uno es grande y noble en sí.

Wasbington University $23-\mathrm{IX}-63$

IVAN A. SCHULMAN

98 Escrito este ensayo nos llega el último libro de Manuel Pedro González, José Martí, en el octogésimo aniversario de la iniciación modernista, $1882-1962$ (Caracas: Ministerio de Educación, 1962) en que se rectifica de nuevo la cronología modernista, sosteniendo que Dario no inició el modernismo, y que Martí, Nájera, Casal y Silva no son los precursores de esta renovación literaria, sino modernistas ciento po: ciento. También se afirma que el modernismo surge primero en la prosa y que sus iniciadores son Martí y Nájera. Hay muchas otras ideas enjundiosas que sería imposible resumir en este lugar. Pero, en cuanto a la cronología modernista, deseamos hacer notar que el profesor González da como fecha de la inauguración del modernismo - reconociendo, por supuesto, la existencia de relevantes antecedentes- el año de 1882. 